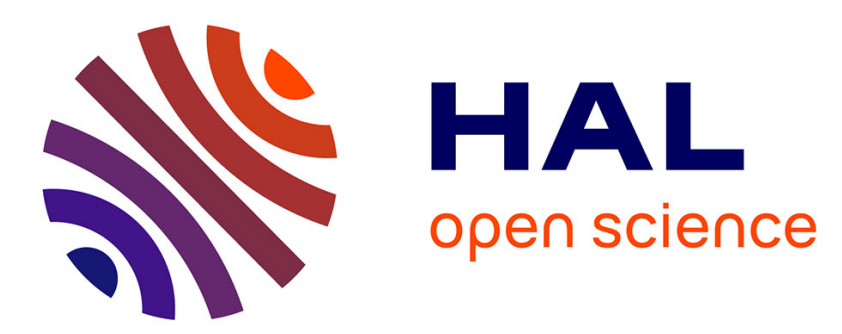

\title{
Neuronal 5-HT metabotropic receptors: fine-tuning of their structure, signaling, and roles in synaptic modulation
}

Joël Bockaert, Sylvie Claeysen, Carine Becamel, Aline Dumuis, Philippe Marin

\section{To cite this version:}

Joël Bockaert, Sylvie Claeysen, Carine Becamel, Aline Dumuis, Philippe Marin. Neuronal 5-HT metabotropic receptors: fine-tuning of their structure, signaling, and roles in synaptic modulation. Cell and Tissue Research, 2006, 326 (2), pp.553-572. 10.1007/s00441-006-0286-1 . hal-02484323

\section{HAL Id: hal-02484323 \\ https://hal.science/hal-02484323}

Submitted on 19 Feb 2020

HAL is a multi-disciplinary open access archive for the deposit and dissemination of scientific research documents, whether they are published or not. The documents may come from teaching and research institutions in France or abroad, or from public or private research centers.
L'archive ouverte pluridisciplinaire HAL, est destinée au dépôt et à la diffusion de documents scientifiques de niveau recherche, publiés ou non, émanant des établissements d'enseignement et de recherche français ou étrangers, des laboratoires publics ou privés. 


\title{
Neuronal 5-HT metabotropic receptors: fine-tuning of their structure, signaling, and roles in synaptic modulation
}

Joël Bockaert ${ }^{1,2,3,4,5^{*}}$ Sylvie Claeysen ${ }^{1,2,3,4,5}$, Carine Bécamel ${ }^{1,2,3,4,5}$, Aline Dumuis ${ }^{1,2,3,4,5}$, Philippe $\operatorname{Marin}^{1,2,3,4,5}$

${ }^{1}$ CNRS, UMR5203, Montpellier F-34094, France

${ }^{2}$ INSERM, U661, Montpellier F-34094, France

${ }^{3}$ Univ Montpellier I, Montpellier F-34094, France

${ }^{4}$ Univ Montpellier II, Montpellier F-34094, France

${ }^{5}$ Institut de Génomique Fonctionnelle, Département de Neurobiologie, 141 Rue de la Cardonille, Montpellier, Cedex 5 F-34094, France

${ }^{*}$ Corresponding author. E-mail: joel.bockaert@igf.cnrs.fr

\begin{abstract}
Serotonin (5-hydroxytryptamine, 5-HT) is, without doubt, the neurotransmitter for which the number of receptors is the highest. Fifteen genes encoding functional 5-HT receptors have been cloned in mammalian brain. 5- $\mathrm{HT}_{3}$ receptors are ionotropic receptors, whereas all the others are metabotropic Gprotein-coupled receptors (GPCRs). 5-HT receptor diversity is further increased by post-genomic modifications, such as alternative splicing (up to 10 splice variants for the 5- $\mathrm{HT}_{4}$ receptor) or by mRNA editing in the case of $5-\mathrm{HT}_{2 \mathrm{C}}$ receptors. The cellular and behavioral implications of 5- $\mathrm{HT}_{2 \mathrm{C}}$ receptor editing are of great physiological importance. Signaling of 5-HT receptors involves a great variety of pathways, but only some of these have been demonstrated in neurons. The classical view of neurotransmitter receptors localized within the synaptic cleft cannot be applied to 5-HT receptors, which are mostly (but not exclusively) localized at extra-synaptic locations either pre- or post-synaptically. 5HT receptors are engaged in pre- or post-synaptic complexes composed of many GPCR-interacting proteins. The functions of these proteins are starting to be revealed. These proteins have been implicated in targeting, trafficking to or from the membrane, desensitization, and fine-tuning of signaling.
\end{abstract}

Keywords: Serotonin; Serotonin receptors; G-protein-coupled receptors; Receptosome; Signaling 


\section{Introduction}

Serotonin (5-hydroxytryptamine, 5-HT) is certainly one of the neurotransmitters that the general public knows the best but is also the most intriguing for researchers. The name "serotonin" retained in the literature indicates its presence in the serum (released from platelets; Rapport et al. 1948); however, 5HT has also been called "enteramine" because of its early recognized presence, at high concentrations, in enterochromaffin cells ( $95 \%$ of $5-\mathrm{HT}$ is found in platelets and the gastro-intestinal tract; Erspamer and Asero 1952). Serotonin is one of the oldest signaling substances to appear during evolution in coelenterates, arthropods, molluscs, tunicates, and vertebrates (Collier 1958). Unsurprisingly, therefore, serotonergic neurons are also among the earliest neurons to be generated during mammalian development, with 5-HT being released before conventional synapses are established (Gaspar et al. 2003). 5-HT is well known by the public, thanks to its roles in normal physiology including sleep, appetite, thermoregulation, and pain perception, and more importantly in human pathologies such as migraine, depression, fear and anxiety, obsessive compulsive disorders, schizophrenia, and addiction. A provocative role for serotonin systems in spiritual experiences has also been proposed in a recent article, published in a respected journal, by Borg et al. (2003), although whether this can be taken seriously remains debatable. 5-HT, like a few other neurotransmitters such as acetylcholine, glutamate, and $\gamma$-aminobutyric acid (GABA), acts via two categories of receptors: ionotropic and metabotropic receptors. Ionotropic receptors (channel receptors) have a low affinity for their neurotransmitter ligand but a rapid activation constant (a few milliseconds). In contrast, metabotropic receptors (receptors acting through $\mathrm{G}$ protein activation and second messenger production) exhibit both a high affinity for their neurotransmitter and a slow activation constant (in seconds or longer). Fifteen genes encoding 5-HT receptors (5-HTR) have been cloned in the mammalian brain (Hoyer and Martin 1997). Recently, three novel 5- $\mathrm{HT}_{3}$-like genes (5- $\mathrm{HT}_{3 \mathrm{C}}, 5-\mathrm{HT}_{3 \mathrm{D}}$, and 5- $\mathrm{HT}_{3 \mathrm{E}}$ ) have been identified (Niesler et al. 2003), but to date, no functional analysis has been published. The 5- $\mathrm{HT}_{3}$ receptors are ionotropic receptors (Van Hooft and Yakel 2003) and will not be discussed in this review. The others are G-protein-coupled receptors (GPCRs) with seven transmembrane domains. They can be categorized into four groups according to their main second messenger system: the $5-\mathrm{HT}_{1}$ receptors coupled to $\mathrm{G} \alpha_{\mathrm{i}} / \mathrm{G}_{\mathrm{o}}$ proteins $\left(5-\mathrm{HT}_{1 \mathrm{~A}}, 5-\mathrm{HT}_{1 \mathrm{~B}}\right.$, $\left.5-\mathrm{HT}_{1 \mathrm{D}}, 5-\mathrm{HT}_{1 \mathrm{E}}, 5-\mathrm{HT}_{1 \mathrm{~F}}\right)$; the $5-\mathrm{HT}_{2}$ receptors coupled to $\mathrm{G \alpha}_{\mathrm{q}}$ proteins $\left(5-\mathrm{HT}_{2 \mathrm{~A}}, 5-\mathrm{HT}_{2 \mathrm{~B}}, 5-\mathrm{HT}_{2 \mathrm{C}}\right)$; the $5-\mathrm{HT}_{4}, 5-\mathrm{HT}_{6}$, and 5- $\mathrm{HT}_{7}$ receptors coupled to $\mathrm{G}_{\mathrm{s}}$ proteins; and the 5- $\mathrm{HT}_{5}$ receptors $\left(5-\mathrm{HT}_{5 \mathrm{~A}}\right.$ and $5-\mathrm{HT}_{5 \mathrm{~B}}$ ) for which the coupling is still uncertain (Raymond et al. 2001). The diversity of metabotropic 5-HTR proteins is further increased by post-genomic modifications, such as alternative splicing and mRNA editing. This will be the subject of the first part of this review. Their neuronal localization, including the synaptic localization when known, and their signaling pathways will be discussed in the second section. The third part deals with the nature and functions of a variety of GPCR-interacting proteins (GIPs; Bockaert et al. 2003, 2004b) that form, together with 5-HTRs, "receptosomes" implicated in their targeting and trafficking and in the fine tuning of their signaling properties. For lack of space, this review will often take illustrative examples rather than being exhaustive. 


\section{Genomic and post-genomic complexity of 5-HT metabotropic receptor structure}

\subsection{Gene structure}

Metabotropic 5-HTRs are generated from 12 different genes in the human genome (NCBI, Map Viewer at http://www.ncbi.nlm.nih.gov/mapview/). These genes diverged from a common ancestor, and their structure reflects their evolutionary relationship (Barnes and Sharp 1999). 5- $\mathrm{HT}_{1} \mathrm{Rs}$ are coded by intronless genes and clearly constitute a subgroup of genes that were derived from a duplicated ancestor (Fig. 1). 5- $\mathrm{HT}_{2} \mathrm{R}$ genes are also closely related to two similar introns located at the end of transmembrane domain 2 (TM2) and within TM4-coding sequences. The 5- $\mathrm{HT}_{2 \mathrm{C}} \mathrm{R}$ gene presents an additional intron in the extracellular domain of the coding sequences and extends over more than $183 \mathrm{~kb}$. Alternative splicing of the $5-\mathrm{HT}_{2} \mathrm{R}$ genes does not generate any functional splice variant (Xie et al. 1996). The $5-\mathrm{HT}_{4} \mathrm{R}$ gene is far more complex. The coding sequence extends over more than $185 \mathrm{~kb}$ and includes at least 14 exons leading to multiple splicing combinations. To date, ten functional splice variants have been described that can be generated by alternative splicing of the human transcript (Bender et al. 2000; Hiroi et al. 2001). For nine of these variants, splicing gives rise to alternate C-terminal domains (Fig. 1). As some exons (such as the $\mathrm{h}$ or the $\mathrm{i}$ exons), in the $5-\mathrm{HT}_{4} \mathrm{R}$ gene, do not present any in-frame stop codons, many additional combinations probably remain to be discovered (Brattelid et al. 2004). The relevance and the functional role of such a multiplicity of isoforms also remain to be elucidated. The finding that the lesswell represented 5- $\mathrm{HT}_{4} \mathrm{R}$ splice variants (e.g., 5- $\mathrm{HT}_{4(\mathrm{a})} \mathrm{R}$ and 5- $\mathrm{HT}_{4(\mathrm{e})} \mathrm{R}$ ) interact with specific intracellular proteins supports the view that these isoforms are in charge of the fine regulation of signal transduction and are not the result of transcriptional leakage (Joubert et al. 2004). Two 5-HT ${ }_{5} \mathrm{R}$ genes have been described in the rodent, but only the $5-\mathrm{HT}_{5 \mathrm{~A}} \mathrm{R}$ can be generated in humans (Rees et al. 1994). A 5- $\mathrm{HT}_{5 \mathrm{~B}} \mathrm{R}$ pseudogene had been localized on chromosome 2 in Build 35.1 of the human genome. However, this annotation has been suppressed in the actual build (36.1). The 5- $\mathrm{HT}_{6} \mathrm{R}$ gene presents a splicing site that lies in the middle of the intracellular loop 3 and that is similar to the splicing site found in the 5-HT ${ }_{5 \mathrm{~A}} \mathrm{R}$ gene. Two separate exons encode TM6 and TM7 of the 5-HT 6 R. A non-functional splice variant has been described for this receptor (Olsen et al. 1999). The human $5-\mathrm{HT}_{7} \mathrm{R}$ gene is more complex: different acceptor and donor sites can be used to generate three receptors that differ in the composition and length of their C-terminal domains $\left(5-\mathrm{HT}_{7(\mathrm{a})}, 5-\mathrm{HT}_{7(\mathrm{~b})}\right.$, and 5- $\left.\mathrm{HT}_{7(\mathrm{~d})}\right)$. Because of its altered intron-exon organization, the rat gene generates the $5-\mathrm{HT}_{7(\mathrm{c})}$ but not the $5-\mathrm{HT}_{7(\mathrm{~d})}$ ) isoform (Heidmann et al. 1997). This splicing position giving rise to alternate Cterminus is similar to that found in the $5-\mathrm{HT}_{4} \mathrm{R}$ gene. The different $\mathrm{C}$-terminal domains of the $5-\mathrm{HT}_{7} \mathrm{R}$ variants probably recruit specific sets of intracellular proteins that might modulate their function as demonstrated for the $5-\mathrm{HT}_{4} \mathrm{R}$ isoforms. 


\subsection{Editing}

RNA editing is a dynamic mechanism that generates molecular and functional diversity. The most common type of RNA editing involves nucleotide substitution that consists of either cytidine to uridine ( $\mathrm{C}$ to $\mathrm{U}$ ) or, most frequently, adenosine to inosine (A to I). Inosine is read as guanosine by the translational machinery of the cell (Higuchi et al. 1993). The 5- $\mathrm{HT}_{2 \mathrm{C}} \mathrm{R}$ is the only known GPCR to be regulated by editing. Editing takes place at four major positions on exon $\mathrm{V}$ (corresponding to the second exon in the coding sequence; Fig. 1), termed sites A, B, C, and D, and one minor site, termed E (Fig. 2a). 5- $\mathrm{HT}_{2 \mathrm{C}} \mathrm{R}$ mRNA editing has been identified as A to I discrepancies between genomic and cDNA sequences in the region encoding the second intracellular loop of the receptor. This A to I substitution alters the coding potentials of three codons. Theoretically, 5- $\mathrm{HT}_{2 \mathrm{C}} \mathrm{R}$ editing can generate up to 32 different mRNAs that encode 24 receptor isoforms from the non-edited form (INI) to the fully edited form (VGV; Fitzgerald et al. 1999; Fig. 2). The editing of 5-HT2C transcripts is tissue-specific. Seven major 5-HT $\mathrm{H}_{2 \mathrm{C}} \mathrm{R}$ isoforms, encoded by 11 distinct RNA species, are expressed in rat brain compared with 14 receptor isoforms encoded by 23 trancripts in human brain. The most prevalent isoform in human brain is $5-\mathrm{HT}_{2 \mathrm{C}}-\mathrm{VSV}$, whereas $5-\mathrm{HT}_{2 \mathrm{C}}-\mathrm{VNV}$ is the most abundant in the rat (Fig. $2 \mathrm{~b}$ ).

\section{Neuronal and synaptic localizations and signaling functions}

The classical view of pre-synaptic 5-HT-containing terminals forming synaptic contacts has been challenged by the team of L. Descarries (Descarries et al. 1975). This does not mean that classical 5-HT synapses do not occur, but they are not largely present. Nerve endings often lack the junction membrane specialization that characterizes the synapse. The released 5-HT may diffuse in the extracellular space and reach relatively distant targets. Moreover, the pleiotropic functions of serotonin are not only exerted by the concerted actions of multiple serotonin receptor subtypes but also by the multiple coupling of each receptor subtype. We will focus, in this review, on signaling in native brain tissues.

\subsection{5-HT ${ }_{1 \mathrm{~A}} \mathrm{Rs}$}

The highest density of 5-HT ${ }_{1 \mathrm{~A}} \mathrm{Rs}$ is found in the limbic areas (Lanfumey and Hamon 2004). 5-HT auto-receptors are localized in cell bodies and dendrites of 5-HT neurons of the dorsal and median raphe nuclei (Sotelo et al. 1990; Riad et al. 2000; Fig. 3a). They are chiefly expressed along extra-synaptic sites, as previously seen for many metabotropic GPCRs ( $\operatorname{Riad}$ et al. 2000). At the post-synaptic level, such as the hippocampal formation, they are localized on dendrites of pyramidal and granule cells (Fig. 3a; Riad et al. 2000). 5-HT ${ }_{1 \mathrm{~A}} \mathrm{Rs}$ are negatively coupled to adenylyl cyclase (AC) via pertussis-toxinsensitive $\mathrm{G} \alpha_{\mathrm{i}}$ and/or $\mathrm{G} \alpha_{\mathrm{o}}$ proteins (De Vivo and Maayani 1986; Weiss et al. 1986; Fig. 4). However, 5$\mathrm{HT}_{1 \mathrm{~A}} \mathrm{Rs}$ do not seem to be coupled to AC inhibition in dorsal raphe nuclei, in spite of their high density 
within these nuclei. Not only 5-HT ${ }_{1 \mathrm{~A}}$ auto-receptors, but also post-synaptic 5-HT ${ }_{1 \mathrm{~A}} \mathrm{Rs}$ inhibit neuronal firing. This inhibition is attributable to the activation of G-protein-gated inwardly rectifying potassium (GIRK) currents and the inhibition of $\mathrm{Ca}^{2+}$ channels (Andrade et al. 1986; Oleskevich 1995; Sodickson and Bean 1998; Fig. 4). Activation of 5-HT $\mathrm{HT}_{1 \mathrm{~A}}$ auto-receptors delays the action of selective serotonin reuptake inhibitors (SSRIs). Indeed, SSRIs are efficient at the post-synaptic level only after desensitization of 5- $\mathrm{HT}_{1 \mathrm{~A}}$ auto-receptors (Adell et al. 2005). For unknown reasons, 5-HT $\mathrm{T}_{1 \mathrm{~A}}$ autoreceptors desensitize much faster and to a much greater extent than post-synaptic receptors (Karschin et al. 1991). In serotonin transporter (SERT) knock-out mice, 5-HT ${ }_{1 \mathrm{~A}}$ auto-receptors are desensitized and down-regulated in the dorsal raphe nuclei, but not in the hippocampus (Fabre et al. 2000). Interestingly, $5-\mathrm{HT}_{1 \mathrm{~A}} \mathrm{Rs}$ inhibit N-methyl-D-aspartate (NMDA) function in prefrontal pyramidal neurons by decreasing the transport and expression of NR2B subunits into dendrites (Yuen et al. 2005). This effect may explain the inhibition of long-term potentiation (LTP) by 5-HT ${ }_{1 \mathrm{~A}} \mathrm{Rs}$ (Edagawa et al. 1998). 5$\mathrm{HT}_{1 \mathrm{~A}} \mathrm{R}$ activation stimulates neurogenesis in the dentate gyrus and the subventricular zone (Brezun and Daszuta 1999), an effect that seems to be required for antidepressant effects (Santarelli et al. 2003). They also reduce the length of dendrites and the number of spines (Yan et al. 1997). 5- $\mathrm{HT}_{1 \mathrm{~A}} \mathrm{R}$ agonists have been developed for anxiety. $5-\mathrm{HT}_{1 \mathrm{~A}} \mathrm{R}$ invalidation consistently increases anxiety in mice (Gross and Hen 2004; Lanfumey and Hamon 2004). Positive coupling of 5-HT ${ }_{1 \mathrm{~A}} \mathrm{Rs}$ to AC, phospholipase C (PLC) and extracellular signal-regulated kinases (ERK) pathways have only been seen in heterologous systems (Raymond et al. 2001) (Fig. 4).

\subsection{5-HT ${ }_{1 \mathrm{~B}} \mathrm{Rs}$ and 5-HT $\mathrm{H}_{1 \mathrm{D}} \mathrm{Rs}$}

$5-\mathrm{HT}_{1 \mathrm{~B}} \mathrm{Rs}$ and $5-\mathrm{HT}_{1 \mathrm{D}} \mathrm{Rs}$ are not expressed on cell bodies of 5-HT neurons but on terminals of 5-HT neurons and on terminals of other neurons, such as dopaminergic, GABAergic, and glutamatergic neurons, where they inhibit neurotransmitter release (Starke et al. 1989; Pauwels 1997; Sari et al. 1997; Riad et al. 2000). They are highly expressed in the substantia nigra and the globus pallidus (probably on striato-pallidal and striato-nigral GABAergic neurons). $5-\mathrm{HT}_{1 \mathrm{~B}} \mathrm{Rs}$ and $5-\mathrm{HT}_{1 \mathrm{D}} \mathrm{Rs}$ are also present in the cortex. $5-\mathrm{HT}_{1 \mathrm{~B} / 1 \mathrm{D}}$ agonists (triptans) are active with respect to migraine, probably by inhibiting trigeminal neurotransmission. $5-\mathrm{HT}_{1 \mathrm{~B}} \mathrm{Rs}$ are also present on thalamo-cortical axon terminals carrying sensory afferents from one whisker. These terminals form clusters, called barrels (Gaspar et al. 2003), in layer IV (Fig. 3b). 5-HT ${ }_{1 \mathrm{~B}} \mathrm{Rs}$, like the other 5-HT, Rs, are negatively coupled to $\mathrm{AC}$ via $\mathrm{G} \alpha_{\mathrm{i}} / \mathrm{G} \alpha_{\mathrm{o}}$ in native brain tissues, such as the substantia nigra (Bouhelal et al. 1988; Fig. 4). In transfected cells, 5$\mathrm{HT}_{1 \mathrm{~B}} \mathrm{Rs}$ regulate PLC, PLD, Akt kinase, neuronal nitric oxide synthase (nNOS), and ERK pathways, activate $\mathrm{K}^{+}$channels, and inhibit $\mathrm{Ca}^{2+}$ channels (Raymond et al. 2001; Fig. 4). Pharmacological and genetic studies suggest a role for $5-\mathrm{HT}_{1 \mathrm{~B}} \mathrm{Rs}$ in the pathophysiology of obsessive-compulsive disorders, drug addiction, depression, and sleep. 5- $\mathrm{HT}_{1 \mathrm{~B}} \mathrm{R}$ knock-out mice are aggressive (Gingrich and Hen 2001). Both in vitro and in vivo experiments indicate that $5-\mathrm{HT}_{1 \mathrm{~B}} \mathrm{Rs}$ control the development of axonal harbors 
and axon terminal clustering (Gaspar et al. 2003). 5- $\mathrm{HT}_{1 \mathrm{E}} \mathrm{Rs}$ and 5- $\mathrm{HT}_{1 \mathrm{~F}} \mathrm{Rs}$ These receptor subtypes are present in the brain, but little data concerning their neuronal localization are available. $5-\mathrm{HT}_{1 \mathrm{~F}} \mathrm{R}$ has been found on pre-synaptic trigeminal nerve terminals and mediates some of the effect of a new generation of triptans (rizatriptan, naratriptan, zolmitriptan; Lanfumey and Hamon 2004). Negative coupling to AC has been demonstrated in heterologous cells, but not neurons (Raymond et al. 2001; Fig. 4).

\subsection{5- $\mathrm{HT}_{2 \mathrm{~A}} \mathrm{Rs}$}

5-HT innervation of the prefrontal cortex has received extensive attention from neuroanatomists, physiologists, and pharmacologists (Leysen 2004). 5- $\mathrm{HT}_{2 \mathrm{~A}} \mathrm{Rs}$ are particularly abundant in the pre-frontal cortex (Fig. 3c; Jakab and Goldman-Rakic 1998; Cornea-Hebert et al. 1999, 2002; Miner et al. 2003) and are certainly the site of action of hallucinogens, such as LSD (Aghajanian and Marek 1999b), and of some atypical anti-psychotics, such as clozapine and risperidone (Adell et al. 2005). Alterations in 5$\mathrm{HT}_{2 \mathrm{~A}} \mathrm{R}$ function may be a contributing factor to the cognitive impairment in mental disorders such as schizophrenia and depression (Kroeze and Roth 1998). Light- and electron-microscopic immunohistochemistry has been used to determine the cellular and subcellular localization of 5-HT ${ }_{2 \mathrm{~A}} \mathrm{Rs}$ in the pre-frontal cortex (Jakab and Goldman-Rakic 1998; Cornea-Hebert et al. 1999, 2002; Miner et al. 2003; represented in Fig 3c). A dense localization has been found in apical dendrite shafts, proximal to the pyramidal cell soma (Jakab and Goldman- Rakic 1998). Some receptors are present in the soma of pyramidal cells and in the dendrites of local circuited neurons (Jakab and Goldman-Rakic 1998). In one study (Miner et al. 2003), but not in another one (Jakab and Goldman-Rakic 1998), a dense localization has been found on the spine heads and necks of pyramidal neurons. A marked intracellular density of 5$\mathrm{HT}_{2 \mathrm{~A}} \mathrm{Rs}$, which may serve as a receptor reserve for trafficking to the plasmamembrane, has also been described (Cornea-Hebert et al. 1999, 2002). A minority of 5-HT $\mathrm{H}_{2 \mathrm{~A}} \mathrm{Rs}$ is also found on axon terminals (Jakab and Goldman-Rakic 1998; Miner et al. 2003). Whether 5-HT ${ }_{2 A}$ Rs are localized on pre-synaptic glutamatergic terminals remains a matter of debate. In the primate cortex, a pre-synaptic localization on glutamatergic terminals has also been reported (Jakab and Goldman-Rakic 1998) although at low levels, whereas in the rat cortex, such a localization remains to be established (Miner et al. 2003). Some of these discrepancies may be related to the nature of the antibodies used. In the rat prefrontal cortex, 5$\mathrm{HT}_{2 \mathrm{~A}} \mathrm{Rs}$ have also been detected on terminals of aminergic fibers (Miner et al. 2003), which may explain the stimulation of this neurotransmitter release following 5- $\mathrm{HT}_{2 \mathrm{~A}} \mathrm{R}$ activation (Pehek et al. 2001). In vitro electrophysiological studies indicate that $5-\mathrm{HT}_{2 \mathrm{~A}} \mathrm{Rs}$ enhance spontaneous excitatory post-synaptic currents (EPSCs; Aghajanian and Marek 1999a; Marek and Aghajanian 1999; Zhou and Hablitz 1999). Activation of 5-HT ${ }_{2 \mathrm{~A}} \mathrm{Rs}$ also increases late EPSPs evoked by the electrical stimulation of afferent fibers (Adell et al. 2005). These effects are probably mediated by a release of glutamate and subsequent activation of $\alpha$-amino-3-hydroxy- 5-methylisoxazole-4-proprionic acid (AMPA) receptors, since they 
are inhibited by AMPA antagonists (Aghajanian and Marek 1999a) and by pre-synaptic group II metabotropic glutamate agonists, which are known to inhibit glutamate release (Marek et al. 2000). A presynaptic localization of 5- $\mathrm{HT}_{2 \mathrm{~A}} \mathrm{Rs}$ on glutamatergic terminals may explain these results. However, if 5- $\mathrm{HT}_{2 \mathrm{~A}} \mathrm{Rs}$ are primarily localized on spine heads of pyramidal cells at asymmetric synapses receiving glutamate innervation, one has to speculate a post-synaptic influence on pre-synaptic glutamatergic release. This could be achieved via the postsynaptic production of a retrograde messenger. An increase in neuronal excitability may also be explained by a $5-\mathrm{HT}_{2 \mathrm{~A}} \mathrm{R}$-mediated inhibition of afterhyperpolarizations (IsAHP) in the prefrontal cortex (Villalobos et al. 2005). However, the situation may be more complex because 5-HT inhibits (rather than stimulates) cortical pyramidal neuron activity in vivo (Zhou and Hablitz 1999). This could be the result of several synaptic effects. 5- $\mathrm{HT}_{2 \mathrm{~A}}$ Rs induce a massive enhancement of spontaneous inhibitory post-synaptic currents (IPSCs) in pyramidal neurons via the activation of interneurons (Zhou and Hablitz 1999), an inhibition of the $\mathrm{Na}^{+}$current, which reduces dendritic excitability (Carr et al. 2002), an inhibition of the L-type $\mathrm{Ca}^{2+}$ current (Day et al. 2002), and an inhibition of NMDA receptor-mediated transmission (Arvanov et al. 1999). Indeed, depending on the kinetics of all these effects and on the kinetics of their desensitization, 5-HT ${ }_{2} \mathrm{Rs}$ may inhibit or excite pyramidal neuron activity. Normal cognitive functions may depend on a fine-tuning of these opposing types of regulation (Williams et al. 2002). Interestingly, both the supra-normal level of 5-HT and the depletion of 5-HT result in altered spatial working memory and decision making, respectively (Williams et al. 2002). Other electrophysiological studies suggest pre- and postsynaptic localizations of 5-HT2A/2CRs in the spinal cord. In superficial dorsal horn synapses, pre-synaptic 5-

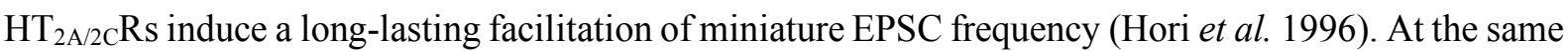
synapses, postsynaptic 5- $\mathrm{HT}_{2 \mathrm{~A} / 2 \mathrm{C}} \mathrm{Rs}$ transforms silent glutamatergic synapses into active synapses, a mechanism that requires the interaction of AMPA receptors with PDZ-domain-containing proteins (post-synaptic density/disc large/zona occludens- 1 proteins; Li and Zhuo 1998; Li et al. 1999). With regard to second messenger production, 5-HT $\mathrm{H}_{\mathrm{A}} \mathrm{Rs}$ activate PLC, PLA2, and the ERK pathway in neurons (Raymond et al. 2001). They also activate the Janus kinase (JAK)/transcription (STAT) pathway in skeletal and smooth muscle (Guillet-Deniau et al. 1997; Banes et al. 2005) and PLD in nonneuronal cells (Raymond et al. 2001; Fig. 4). Unexpectedly, some antagonists (mianserin, spiperone, mesulergine) induce desensitization and internalization of 5- $\mathrm{HT}_{2 \mathrm{~A}} \mathrm{Rs}$ both in vivo and in vitro (SandersBush 1990; Roth and Ciaranello 1991). This process may contribute to the redistribution of 5-HT ${ }_{2 A} R s$ from the membrane of apical dendrites to the cytoplasm of neuronal cell bodies following chronic treatment of rats with atypical antipsychotics (Willins et al. 1999).

\subsection{5- $\mathrm{HT}_{2 \mathrm{~B}} \mathrm{Rs}$}

In the adult brain, $5-\mathrm{HT}_{2 \mathrm{~B}} \mathrm{Rs}$ are found only in discrete nuclei of the cerebellum, the lateral septum, the dorsal hypothalamus, and the medial amygdala, contrasting with its wide expression in peripheral 
tissues, including the heart and lung. As 5- $\mathrm{HT}_{2 \mathrm{~A}} \mathrm{Rs}, 5-\mathrm{HT}_{2 \mathrm{~B}} \mathrm{Rs}$ are coupled to $\mathrm{G} \alpha_{\mathrm{q}}$ proteins and activate PLC. However, to date, no study has reported such a coupling within neurons (Wainscott et al. 1993). 5 - $\mathrm{HT}_{2 \mathrm{~B}} \mathrm{Rs}$ have also been reported to stimulate $\mathrm{Ca}^{2+}$ mobilization in astrocytes derived from various rat cerebral regions (Sanden et al. 2000). Additional 5- $\mathrm{HT}_{2 \mathrm{~B}} \mathrm{R}-$ mediated signaling pathways have been described in non-neuronal cells expressing endogenous $5-\mathrm{HT}_{2 \mathrm{~B}} \mathrm{Rs}$. Stimulation of the $5-\mathrm{HT}_{2 \mathrm{~B}} \mathrm{R}$ is associated with an increase in cyclic GMP through the dual activation of constitutive and inducible NOS. G $\alpha_{\mathrm{q} / 11}$-coupled 5-HT $\mathrm{H}_{2 \mathrm{~B}} \mathrm{Rs}$ also activate PI3K/Akt and $\mathrm{ERK}_{1 / 2}$ signaling pathways (Raymond et al. 2001) (Fig. 4).

\subsection{5- $\mathrm{HT}_{2 \mathrm{CRs}}$}

A comparison of the distribution of 5- $\mathrm{HT}_{2 \mathrm{C}} \mathrm{R}$ mRNA with that of $5-\mathrm{HT}_{2 \mathrm{C}} \mathrm{R}$ protein labeled with ${ }^{3} \mathrm{H}-$ mesulergine in monkey and human brains has revealed both pre- and postsynaptic localizations of 5$\mathrm{HT}_{2 \mathrm{C}} \mathrm{R}$ (Lopez-Gimenez et al. 2001; Leysen 2004). These pre- and post-synaptic localizations of 5 $\mathrm{HT}_{2 \mathrm{C}} \mathrm{Rs}$ have been further confirmed by electron-microscopic studies performed in the mouse (Becamel et al. 2004; Fig. 3d). Data on the localization of 5- $\mathrm{HT}_{2 \mathrm{CRs}}$ in the ventral tegmental area (VTA) are not consensual. Some suggest that $5-\mathrm{HT}_{2 \mathrm{C}} \mathrm{Rs}$ are primarily localized on non-dopaminergic neurons, probably GABAergic neurons (Di Matteo et al. 2001). These receptors may be constitutively active (Berg et al. 2005), yielding tonic GABAergic inhibition of dopaminergic neurons. Other data suggest that $5-\mathrm{HT}_{2} \mathrm{R}$ Rs are localized on dopaminergic neurons (Ji et al. 2006; Fig. 3d). Indeed, all studies agree that the activation of $5-\mathrm{HT}_{2 \mathrm{C}} \mathrm{Rs}$ inhibits dopaminergic neurons (Gobert et al. 2000; Ji et al. 2006). Atypical anti-psychotics and particularly those with inverse agonism release this inhibition, providing a way to activate dopaminergic systems (Gobert et al. 2000; De Deurwaerdere et al. 2004; Berg et al. 2005). This activation may be relevant for the treatment of depression and the negative symptoms of schizophrenia. In kittens, $5-\mathrm{HT}_{2 \mathrm{CRs}}$ have a characteristic columnar expression in layer IV of the visual cortex during the critical period for ocular dominance plasticity. $5-\mathrm{HT}_{2 \mathrm{C}}$ agonists modulate synaptic plasticity during this period (Gaspar et al. 2003). 5- $\mathrm{HT}_{2 \mathrm{C}} \mathrm{Rs}$ are also present in hypothalamic proopiomelanocortin (POMC)/cocaine amphetamine-regulated transcript (CART) neurons within the arcuate nucleus (Miller 2005). Activation of POMC/CART neurons inhibits feeding. This is certainly the main reason that $5-\mathrm{HT}_{2} \mathrm{C} /$ mice are obese (Miller 2005). The highest density of 5- $\mathrm{HT}_{2 \mathrm{CRs}}$ is found in epithelial cells of the choroid plexus, where these receptors control spinal fluid production (Leysen 2004). 5- $\mathrm{HT}_{2} \mathrm{R}$ has been reported to activate PLC via $\mathrm{G}_{\mathrm{q} / 11}$ in many brain regions, including the choroid plexus (Sanders-Bush and Breeding 1988; Chang et al. 2000; Fig. 4). These receptors also activate PLD in choroid plexus epithelial cells through a mechanism involving both $G \alpha_{13}$ and $G \beta \gamma$ subunits (McGrew et al. 2002). 5- $\mathrm{HT}_{2 \mathrm{C}} \mathrm{R}$-mediated stimulation of PLA2 and AC have been exclusively described in transfected cells (Raymond et al. 2001; Fig. 4). As observed for 5-HT $\mathrm{H}_{2 \mathrm{As}}$, 5-HT $2 \mathrm{CRs}$ are down-regulated following chronic antagonist exposure (Van Oekelen et al. 2003). However, the effects 
of such treatments are still controversial. Indeed, Schlag and coworkers (2004) have recently demonstrated that only $5-\mathrm{HT}_{2} \mathrm{R}$ agonists and partial agonists promote receptor desensitization and internalization, whereas neither inverse agonists nor neutral antagonists have these effects (Schlag et al. 2004).

Further discussion of 5- $\mathrm{HT}_{2 \mathrm{C}} \mathrm{R}$ signaling, in particular with regard to editing, can be found below (Functions associated with editing).

\subsection{5- $\mathrm{HT}_{4} \mathrm{Rs}$}

5-HT $\mathrm{T}_{4} \mathrm{Rs}$ are mainly present in limbic structures (hypothalamus, nucleus accumbens, amygdala), islands of Calleja, olfactory tubercle, basal ganglia (striatum, globus pallidus), hippocampus, substantia nigra, and septum. Although the immunolocalization of $5-\mathrm{HT}_{4} \mathrm{Rs}$ is still not possible in brain synapses because of a lack of satisfactory antibodies, indirect evidence suggests that most of 5-HT $\mathrm{H}_{4} \mathrm{Rs}$ are localized postsynaptically. However, an heterologous presynaptic localization on terminals of cholinergic, GABAergic (dentate gyrus), dopaminergic, and serotonergic neurons is also likely because of the increase in the release of these neurotransmitters by $5-\mathrm{HT}_{4}$ agonists. Results from lesion studies and electrophysiological studies are also consistent with a pre-synaptic localization of 5-HT ${ }_{4} \mathrm{Rs}_{\text {(Bockaert }}$ et al. 1997, 2004a; Bockaert and Dumuis 1998). Two studies have reported the immunolocalization of $5-\mathrm{HT}_{4} \mathrm{Rs}$. One of them shows the localization of $5-\mathrm{HT}_{4} \mathrm{Rs}$ in respiratory neurons in the pre-Boetzinger complex (Manzke et al. 2003). Half of these neurons co-express $\mu$-receptors and Substance-P-reactive neurokinin-1 (NK1) receptors. Reverse transcription/polymerase chain reaction experiments have confirmed these findings (Manzke et al. 2003). In these neurons, 5- $\mathrm{HT}_{4} \mathrm{R}$ activation overcomes fentanylinduced respiratory depression (by reversing the inhibition of fentanyl-induced cAMP production) and reestablishes stable respiratory rhythms. The second study based on a different antibody has shown the immunostaining of myenteric and submucosal plexuses (Liu et al. 2005). Electron-microscopic analysis has indicated an axonal localization, especially in varicosities that contain large dense-cored and small synaptic vesicles. Electrophysiological data have revealed a pre-synaptic action of $5-\mathrm{HT}_{4} \mathrm{Rs}$ on cholinergic neurons leading to the increase in post-synaptic nicotinic EPSCs in mouse myenteric neurons (Bockaert et al. 2004a; Liu et al. 2005). They are also consistent with observations that 5-HT 4 Rs stimulate acetylcholine release in the myenteric plexus (Kilbinger and Wolf 1992; Kilbinger et al. 1995). 5- $\mathrm{HT}_{4} \mathrm{Rs}$ are positively coupled to $\mathrm{AC}$ in mice colliculi neurons and in guinea pig hippocampal membranes (Dumuis et al. 1988; Bockaert et al. 1990; Fig. 4). In colliculi neurons, the 5-HT4Rsmediated increase in cAMP concentration seen after a short application of agonist leads to the inhibition of voltage-gated $\mathrm{K}^{+}$channels, including $\mathrm{Ca}^{2+}$-activated $\mathrm{K}^{+}$channels, and their closure (Fagni et al. 1992; Ansanay et al. 1995). Moreover, the activation of $5-\mathrm{HT}_{4} \mathrm{Rs}$ produces a long-lasting inhibition of $\mathrm{K}+$ channels because of the long-lasting blockade of phosphatase (Ansanay et al. 1995). In CA1 pyramidal neurons of hippocampus, 5-HT 4 Rs reduce the AHP that follows action potentials. Moreover, 5-HT4R 
activation induces a reduction in spike accommodation (Andrade and Chaput 1991; Torres et al. 1996). These effects are mediated by cAMP and protein kinase A (PKA) activation. 5- $\mathrm{HT}_{1 \mathrm{~A}} \mathrm{Rs}, 5-\mathrm{HT}_{4} \mathrm{Rs}$, and $5-\mathrm{HT}_{7} \mathrm{Rs}$ differentially expressed in CA1 neurons allow space-specific modulation of the hyperpolarization-activated current $\left(\mathrm{I}_{\mathrm{h}}\right)$ current, which is known to adjust synaptic integration and the repetitive discharge behavior of CA1 neurons (Bickmeyer et al. 2002). In prefrontal cortex pyramidal neurons, 5- $\mathrm{HT}_{4} \mathrm{Rs}$ can activate or inhibit GABAergic synaptic transmission. This regulation of the GABAA current is also mediated by cAMP- and PKA-dependent signaling pathways (Cai et al. 2002). In hippocampal neurons, activation of the endogenous $5-\mathrm{HT}_{4} \mathrm{Rs}$ leads to a decrease in the length and number of neurites through the $\mathrm{G \alpha}_{13} / \mathrm{RhoA}$ signaling pathway (Fig. 4; Ponimaskin et al. 2002). Moreover, of note, $5-\mathrm{HT}_{4} \mathrm{R}$ activation, at least in dorsal root ganglion (DRG) cells, is associated with an increase in the tetrodotoxin-insensitive $\mathrm{Na}^{+}$current, but the messenger involved in this effect does not appear to be cAMP (Cardenas et al. 1997). 5-HT4Rs increase, via the production of cAMP, the activated exchange factor, Epac. Epac in turn activates the small G protein Rap1, which increases Ras GTP loading. This Epac-dependent signaling pathway stimulates sAPP $\alpha$ secretion (Lezoualc'h and Robert 2003). In colliculi neurons, the desensitization of $5-\mathrm{HT}_{4} \mathrm{Rs}$ is homologous and results in the activation of G-proteincoupled receptor kinase type 2 (GRK2; Ansanay et al. 1992; Barthet et al. 2005). In heterologous cells, the GRK2 concentration is too low, and homologous desensitization of 5-HT ${ }_{4} \mathrm{Rs}$ does not occur (Barthet et al. 2005). Several reports clearly show the modulation of LTP and long-term depression (LTD) by 5-HT 4 agonists (Kemp and Manahan-Vaughan 2004, 2005). Interestingly, 5$\mathrm{HT}_{4} \mathrm{Rs}$ exert both a tonic and a phasic stimulatory control over dorsal 5-HT raphe neurons (Lucas and Debonnel 2002). This effect might be enhanced by the activation of $5-\mathrm{HT}_{4} \mathrm{Rs}$ expressed in the medial prefrontal cortex (Lucas et al. 2005). 5- $\mathrm{HT}_{4} \mathrm{Rs}$ also positively modulate learning and memory, reward, sensitivity to novelty, and stress (Bockaert et al. 2004a; Compan et al. 2004).

\subsection{5- $\mathrm{HT}_{5} \mathrm{Rs}$}

Studies on the cellular and subcellular localization of 5- $\mathrm{HT}_{5} \mathrm{Rs}$ by using immunohistochemical methods have led to contradictory results. Both astrocytes and neuronal localizations have been reported. One study reports a localization on 5-HT neurons, suggesting a possible role as autoreceptors. However, the quality of the antibodies used and the lack of specific pharmacological tools preclude any definitive conclusion regarding the functional role of these receptors (Nelson 2004). Surprisingly, no study to date has identified a functional coupling of 5- $\mathrm{HT}_{5} \mathrm{Rs}$ in native neuronal tissue. Rat 5- $\mathrm{HT}_{5} \mathrm{R}$ transfected into C6 glioma cells has been shown to couple to the inhibition of cAMP production. In the same C6 glioma cells, one study has reported that the human $5-\mathrm{HT}_{5 \mathrm{~A}} \mathrm{R}$ couples to multiple signal transduction pathways, e.g., the inhibition of cAMP accumulation and of ADP-ribosyl cyclase and the activation of outward currents. This study has indicated that human $5-\mathrm{HT}_{5 \mathrm{~A}} \mathrm{R}$ is coupled to $\mathrm{G} \alpha_{\mathrm{i}} / \mathrm{G \alpha}_{0}$; it also raises the possibility of a cross-coupling of the receptor to $\mathrm{G} \alpha_{\mathrm{q} / 11}$ (Noda et al. 2003; Fig. 4). 


\section{8. $5-\mathrm{HT}_{6} \mathrm{Rs}$}

5- $\mathrm{HT}_{6} \mathrm{Rs}$ are almost exclusively expressed in the central nervous system. They are found at high concentrations in limbic and cortical regions (Woolley et al. 2004) but are not expressed in 5-HT neurons. Immunohistochemical studies including electron-microscopic investigations have shown prominent dendritic localization. Some non-motile cilia of the nucleus accumbens, the caudate-putamen,

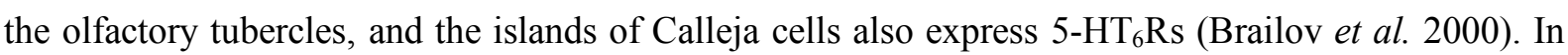
the striatum, $5-\mathrm{HT}_{6} \mathrm{Rs}$ are expressed by medium-sized spiny neurons projecting to the substantia nigra or globus pallidus (Gerard et al. 1997; Sebben et al. 1994). Preferential GABAergic localization is suggested in most brain localizations. No electrophysiological data are available. Selective antagonists have been synthesized and can now be used to investigate the physiological roles of $5-\mathrm{HT}_{6} \mathrm{Rs}$. For example, the selective antagonist SB-271046 has been shown to increase glutamate release probably via deinhibition of GABAergic inhibition (Woolley et al. 2004). Many studies have tried to correlate 5$\mathrm{HT}_{6} \mathrm{R}$ polymorphisms with psychiatric disorders (Woolley et al. 2004). Contradictory results have been reported. Pharmacological studies and localization studies indicate possible roles in psychotic and affective disorders, anxiety, epilepsy, and memory retention but not the regulation of feeding (Woolley et al. 2004). Native 5- $\mathrm{HT}_{6} \mathrm{Rs}$, like 5- $\mathrm{HT}_{4} \mathrm{Rs}$ and $5-\mathrm{HT}_{7} \mathrm{Rs}$, are positively coupled to $\mathrm{AC}$ via the $\mathrm{G} \alpha_{\mathrm{s}}$ protein in striatal tissue or primary cultures of striatal neurons (Schoeffter and Waeber 1994; Sebben et al. 1994). This positive coupling has been confirmed by $5-\mathrm{HT}_{6} \mathrm{Rs}$ being expressed in various heterologous expression models (Ruat et al. 1993; Fig. 4).

\section{9. $5-\mathrm{HT}_{7} \mathrm{Rs}$}

In the brain, 5- $\mathrm{HT}_{7} \mathrm{Rs}$ are mainly found in the thalamus, hypothalamus (suprachiasmatic nucleus), cerebral cortex (both on pyramidal and GABAergic neurons), hippocampus (all CA regions), and amygdala (Hedlund and Sutcliffe 2004; Thomas and Hagan 2004). Most 5-HT ${ }_{7}$ Rs are localized on both the soma and axon terminals (outside the synapses) of GABAergic neurons. Within the cerebellum, 5$\mathrm{HT}_{7} \mathrm{Rs}$ are exclusively located in Purkinje neurons. 5- $\mathrm{HT}_{7} \mathrm{Rs}$ are also found in intra- and extra-cranial blood vessels and meningeal tissues (Hedlund and Sutcliffe 2004). In the guinea pig hippocampus, 5$\mathrm{HT}_{7} \mathrm{Rs}$ have been recognized as being the receptor with a high affinity for 5-carboxamidotryptamine (5CT) coupled to AC (Bockaert et al. 1990, 1997). In heterologous cells, the four 5- $\mathrm{HT}_{7} \mathrm{R}$ splice variants activate cAMP production via the Gas protein (Ruat et al. 1993). 5-HT $\mathrm{R}_{\mathrm{R}}$ also activate the $\mathrm{ERK}_{1 / 2}$ pathway in hippocampal neurons. However, the signaling pathway used by the receptor to activate ERK remains unclear. Most of the 5-HT $\mathrm{H}_{7} \mathrm{R}-$ mediated activation of ERK has been found to be mediated via Gas. Both PKA-dependent and -independent pathways might contribute to ERK activation. Until recently, the pathway for ERK activation was shown to require cAMP, PKA, and MAP kinase (MEK) in neurons endogenously expressing $5-\mathrm{HT}_{7} \mathrm{Rs}$ and in $5-\mathrm{HT}_{7} \mathrm{R}$-transfected cells (including PC12 and 
HEK 293cells; Norum et al. 2003). However, another report indicates that 5- $\mathrm{HT}_{7} \mathrm{Rs}$ activate ERK in hippocampal neurons and transfected PC12 cells through a pathway independent of PKA but requiring a cAMP-GEF, such as Epac (Lin et al. 2003). 5-HT 7 Rs inhibit slow AHP in thalamic and trigeminal motor neurons (Goaillard and Vincent 2002). In vivo, SSRIs increase the population spike amplitude in CA1 and CA3 areas. This effect is blocked by SB-269970-A, a specific 5-HT $\mathrm{R}_{7}$ antagonist (Matsumoto et al. 2002). In the CA1 region and in thalamic and rat DRG neurons, $5-\mathrm{HT}_{7} \mathrm{Rs}_{\text {increases excitability }}$ through a mechanism involving a cAMP-mediated $\mathrm{I}_{\mathrm{h}}$ current (Bickmeyer et al. 2002). All these effects suggest an important role for $5-\mathrm{HT}_{7} \mathrm{Rs}$ in the control of neuronal excitability and may contribute to greater information transfer within a neuronal network. 5- $\mathrm{HT}_{7} \mathrm{Rs}$ endogenously expressed in hippocampal neurons significantly increase neurite length through the $\mathrm{G} \alpha_{12}$, RhoA, and Cdc42 GTPasesdependent signaling pathway (Kvachnina et al. 2005) (Fig 4). Functional studies have also implicated $5-\mathrm{HT}_{7} \mathrm{Rs}$ in thermoregulation and the activation of rapid-eye-movement (REM) sleep via the modulation of suprachiasmatic nucleus neurons (Thomas and Hagan 2004). In this regard, 5-HT 7 R antagonists inhibit REM sleep and increase the latency to onset of REM sleep. This effect suggests that $5-\mathrm{HT}_{7} \mathrm{R}$ antagonists are candidatesfor treating depression, a situation in which the REM sleep is disturbed. A role of $5-\mathrm{HT}_{7} \mathrm{Rs}$ in learning and memory is suggested by the observed decrease in synaptic plasticity in CA1 and contextual fear conditioning in 5- $\mathrm{HT}_{7} \mathrm{R}^{-} \%$ mice (Thomas and Hagan 2004). 5- $\mathrm{HT}_{7} \mathrm{Rs}$ are recognized for their important role in controlling hormonal release not only at the hypothalamic, but also at the peripheral level. A role in pain and migraine (via their action on blood vessels but also on neurogenic inflammation) is under investigation. Finally, a role in schizophrenia remains to be found in animal models (Hedlund and Sutcliffe 2004; Thomas and Hagan 2004).

\section{Fine-tuning of signaling functions}

\subsection{Constitutive activity}

Studies performed mainly in heterologous cells transfected with both native and mutant forms of 5$\mathrm{HT}_{1}$ Rs (Albert et al. 1999; Kiel et al. 2000), 5-HT ${ }_{2} \mathrm{Rs}$ (Egan et al. 1998), 5-HT $\mathrm{H}_{4} \mathrm{Rs}$ (Claeysen et al. 1999), 5- $\mathrm{HT}_{6} \mathrm{Rs}$, and 5-HT $\mathrm{HT}_{7}$ Rs have demonstrated that 5-HTRs can exist in a conformation that mimics an active state of the receptor in the absence of agonist, thus revealing that these receptors display constitutive activity. All these studies highlight the importance of $i_{2}$ and/or $i_{3}$ loops in the regulation of constitutive activity of the majority of 5-HTRs and of the role of the C-terminus in the constitutive activity of 5-HT $\mathrm{H}_{4} \mathrm{R}$ and $5-\mathrm{HT}_{7} \mathrm{R}$ splice variants, which differ in the length of their C-terminal tail (for a review, see Bockaert et al. 2005). However, to date, only 5- $\mathrm{HT}_{2 \mathrm{~A}} \mathrm{Rs}$ and $5-\mathrm{HT}_{2 \mathrm{C}} \mathrm{Rs}$ have been shown to exhibit constitutive activity in vivo (Berg et al. 2005). Harvey (2003) has shown that 5- $\mathrm{HT}_{2 \mathrm{~A}} \mathrm{R}$ inverse agonists, but not neutral antagonists, retard the learning of the conditioned eye link response in rabbits stimulated by LSD. This effect is not attributable to the blockade of endogenous 5-HT by inverse 
agonists, but rather to an inhibition of endogenous constitutive activity, because it occurs after lesions. Evidence of an in vivo constitutive activity of 5- $\mathrm{HT}_{2} \mathrm{Rs}$ has come from experiments by De Deurwaerdere and co-workers (2004); by using microdialysis, they have demonstrated that SB 206553, an inverse agonist, but not the neutral antagonist SB 242084, enhances basal dopamine release in dopamine-innervated areas, such as the frontal cortex, the accumbens nucleus, and the striatum. The effects of the inverse agonist are insensitive to the lesion of 5-HT neurons and are blocked by the neutral antagonist.

\subsection{Functions associated with editing}

As seen above, $5-\mathrm{HT}_{2} \mathrm{C}$ exhibits a unique mechanism of generating multiple functional receptor variants through a process called mRNA editing (Burns et al. 1997). RNA transcripts encoding the 5$\mathrm{HT}_{2} \mathrm{R}$ undergo A to I RNA editing events at up to five sites (see above). In heterologous cells, RNA editing appears to regulate the pattern of intracellular signaling (Burns et al. 1997). The non-edited form $\left(5-\mathrm{HT}_{2 \mathrm{C}-\mathrm{INI}} \mathrm{R}\right)$ is more potent in stimulating PLC and exhibits more constitutive activity than the edited forms (Niswender et al. 1999). Moreover, non-edited 5-HT2C-INI $\mathrm{R}$ is capable of coupling to the $\mathrm{G \alpha}_{13}$ protein (activating the PLD signaling pathway and promoting Rho GTPase activity; McGrew et al. 2004), whereas the fully edited isoform 5- $\mathrm{HT}_{2 \mathrm{C}-\mathrm{VGV}} \mathrm{R}$ fails to activate $\mathrm{G}_{13}$ (Price et al. 2001). RNA editing has an important implication for serotonergic signal transduction in vivo. Editing is regulated by 5-HT itself. Depletion of 5-HT increases the expression of edited forms having a high affinity for 5-HT, whereas stimulation of the 5-HT $\mathrm{H}_{2 \mathrm{~A} / 2 \mathrm{C}} \mathrm{Rs}$ has the opposite effect (Gurevich et al. 2002a). Moreover, altered RNA editing of the 5- $\mathrm{HT}_{2} \mathrm{C}$ may play a role in depression. 5- $\mathrm{HT}_{2 \mathrm{C}}$ mRNA isoforms expressed in human prefrontal cortex differ in tissues obtained from depressed suicide victims compared with healthy controls. In suicides, three abundant isoforms, resulting from an increase at the $\mathrm{E}$ and $\mathrm{C}$ sites and a decrease at the $\mathrm{D}$ site and encoding receptors, are expressed. These isoforms exhibit decreased basal activity and decreased agonist affinity and potency (Gurevich et al. 2002b). Recently, Kishore and Stamm (2006) have reported that the small nucleolar RNA (snoRNA) HBII-52, which exhibits sequence complementarity to the alternative spliced exon $\mathrm{V}$ encoding for a functional 5- $\mathrm{HT}_{2 \mathrm{C}} \mathrm{R}$, regulates receptor mRNA splicing. Notably, Prader-Willy syndrome patients (characterized by neonatal muscular hypotonia, early childhood obesity, hypogonadism, and mental retardation) who do not express HBII52 snoRNA exhibit abnormally low levels of the non-edited 5- $\mathrm{HT}_{2 \mathrm{C}} \mathrm{R}$ isoform, suggesting a role of serotonergic systems in Prader-Willi syndrome (Kishore and Stamm 2006).

\section{5-HTR interacting proteins and modulation of signaling}

The first proteins found to have functional interactions with metabotropic 5-HTRs were, of course, G proteins (see above). Although coupling to $\mathrm{G}$ proteins remains a central event in 5-HTR-mediated 
signaling, an increasing body of evidence indicates that the regulation of their functional status also depends on interactions with a variety of additional protein partners. Like other GPCRs, 5-HTRs associate with $\beta$-arrestins in a manner that is dependent on receptor phosphorylation by GRKs. The binding of arrestins to the receptors promotes their internalization. This process requires the recruitment, by arrestins, of binding partners, including clathrin, the central component of the endocytic machinery, AP2, another endocytic protein, and intracellular trafficking proteins such as NSF, ARF6, and ARNO (Lefkowitz and Shenoy 2005). $\beta$-Arrestins also serve as scaffolds for signaling enzymes such as c-Src, members of the MAP kinase pathways, and the c-Jun Nterminal kinase 3, which participate in 5-HTR signaling (Lefkowitz and Shenoy 2005). In addition to the binding to $\beta$-arrestins, which seems to be a general mechanism, 5- HTR subtypes can recruit specific protein partners. This section will describe our current knowledge concerning these subtype-specific interactions. Metabotropic 5-HTRs are certainly the GPCRs for which the highest number of specific accessory proteins have been identified, thanks to methodologies such as the yeast twohydrid screen and proteomic approaches combining affinity chromatography experiments and the identification of receptor partners by mass spectrometry. However, our present cognizance of 5-HTR protein partners fluctuates from one receptor to another. For some 5-HTRs (e.g., 5- $\mathrm{HT}_{2 \mathrm{~A}} \mathrm{R}, 5-\mathrm{HT}_{2 \mathrm{C}} \mathrm{R}$, and several 5-HT $\mathrm{H}_{4} \mathrm{R}$ splice variants), interacting proteins have been extensively characterized by using, in part, proteomic approaches, whereas no binding partner has so far been identified for a number of 5-HTRs (Table 1). As for other GPCRs, most of the hitherto identified 5-HTR interacting proteins associate with their C-terminus, even though some of them have been shown to bind to motifs located on intracellular loops ( $i_{2}$ and $i_{3}$ loops).

\subsection{Proteins interacting with the 5-HTR C-terminal domain}

\subsubsection{PDZ-domain-containing proteins}

The acronym PDZ derives from the three first proteins (PSD-95/Disc large/Zonula occludens-1) in which these domains have been described (Nourry et al. 2003). To date, PDZ proteins are certainly the most numerous proteins involved in the scaffolding of multiprotein complexes that contribute to the targeting, the trafficking, and the fine tuning of signaling properties of membrane-bound receptors, including GPCRs. Genome sequence analysis predicts the presence of more than 300 PDZ proteins in humans. PDZ proteins generally bind to a conserved consensus sequence (PDZ ligand) located at the extreme $\mathrm{C}$-terminus of target receptors. PDZ domains have been classified according to their specificity for these C-terminal motifs. Class I PDZ domains preferentially bind to S/TX $\varphi$, class II to $\varphi \mathrm{X} \varphi$ and class III to $\mathrm{E} / \mathrm{DX} \varphi$ motifs, where $\varphi$ represents a hydrophobic residue and $\mathrm{X}$ any residue (Nourry et al. 2003). Several 5-HTRs express class I or II canonical PDZ ligands, suggesting that they may interact with PDZ-based protein scaffolds. These include the three 5-HT2R subtypes (SCV, SYV/I, and SSV, for 5-HT ${ }_{2 A} \mathrm{R}$, the 5-HT ${ }_{2 \mathrm{~B}} \mathrm{R}$, and 5-HT $2 \mathrm{C}$, respectively), several 5- $\mathrm{HT}_{4} \mathrm{R}$ splice variants $\left(\mathrm{SCF}-5-\mathrm{HT}_{4(\mathrm{a})} \mathrm{R}\right.$, 
VPV-5-HT4(e) $\mathrm{R}$ and 5-HT $4(\mathrm{f}) \mathrm{R}$ ), and one 5-HT $\mathrm{H}_{7} \mathrm{R}$ variant (FVL, 5- $\left.\mathrm{HT}_{7(\mathrm{~b})} \mathrm{R}\right)$. The first evidence of an interaction between one 5-HTR and one PDZ protein was obtained by Ullmer et al. (1998). Screening a human brain cDNA library with the yeast two-hybrid system, this group isolated and cloned a multiPDZ protein (the protein called MUPP1), which interacts with the C-terminal domain of the human 5$\mathrm{HT}_{2 \mathrm{C}}$ receptor. MUPP1, which contains thirteen PDZ domains and no obvious catalytic domains, is the PDZ protein that contains the highest number of PDZ domains identified to date. The $5-\mathrm{HT}_{2 \mathrm{C}} \mathrm{R}$ specifically interacts with the $10^{\text {th }}$ PDZ domain of MUPP1, leaving the other PDZ domains free to interact with additional partners within a larger complex (Becamel et al. 2001; Parker et al. 2003). This interaction is dynamically regulated by agonist-dependent receptor phosphorylation at Ser458, located in the PDZ-binding motif (position-2; Parker et al. 2003). The receptor/MUPP1 interaction induces both conformational changes in the MUPP1 protein (Parker et al. 2003) and receptor clustering at the cell surface (Becamel et al. 2001). MUPP1 also associates with the 5- $\mathrm{HT}_{2 \mathrm{~A}} \mathrm{R}$ and $5-\mathrm{HT}_{2 \mathrm{~B}} \mathrm{R}$, but the functional significance of these interactions remains to be demonstrated (Becamel et al. 2001). A more comprehensive description of $\mathrm{PDZ}$ proteins that interact with $5-\mathrm{HT}_{2 \mathrm{~A}} \mathrm{R}$ and $5-\mathrm{HT}_{2 \mathrm{C}} \mathrm{R} \mathrm{C}$-termini has been performed by using proteomic approaches comparing proteins "fished out" by using the receptor Ctermini as bait and mutant baits in which the $\mathrm{C}$-terminal valine residue, which is critical for interaction with target PDZ domains, has been mutated into an alanine (Becamel et al. 2002; Becamel et al. 2004). These studies have demonstrated that each 5- $\mathrm{HT}_{2} \mathrm{R}$ subtype interacts with specific sets of PDZ proteins, even though they share an identical PDZ ligand (SXV), thereby underpinning the role of residues located outside this canonical sequence in the specificity for PDZ domains (Becamel et al. 2004). They have also revealed that 5-HT $\mathrm{HA}_{2 \mathrm{~A}} \mathrm{Rs}$ only interact with PDZ proteins located at the post-synapse (e.g., PSD-95), whereas $5-\mathrm{HT}_{2 \mathrm{C}} \mathrm{Rs}$ associate with $\mathrm{PDZ}$ proteins exhibiting both presynaptic and post-synaptic localizations (e.g., the Veli3/ CASK/Mint1 complex), consistent with the differential distribution of the receptors at the synaptic junction. The association of 5-HT ${ }_{2 \mathrm{~A}} \mathrm{Rs}$ with PSD-95 has been shown to enhance receptor-mediated signal transduction in heterologous cells, a process that can be related to the ability of PSD-95 to inhibit agonist-induced 5- $\mathrm{HT}_{2 \mathrm{~A}} \mathrm{R}$ internalization (Xia et al. 2003a). The functional consequences of the other interactions remain to be demonstrated. However, several studies with receptors mutated at the $\mathrm{PDZ}$ ligand indicate that $5-\mathrm{HT}_{2} \mathrm{R} / \mathrm{PDZ}$ protein interactions play a critical role in governing receptor targeting in neurons and/or modulating their signal transduction properties. The 5-HT $\mathrm{H}_{\mathrm{A}} \mathrm{R}$ PDZ ligand seems to be essential for preferential receptor targeting to the dendritic compartment of pyramidal cortical neurons (Xia et al. 2003b). The deletion of the 5-HT $2 \mathrm{R}$ PDZ ligand, which prevents agonist-induced receptor phosphorylation (see above), modulates the desensitization/ resensitization of the receptor $\mathrm{Ca}^{2+}$ effector pathway in NIH-3T3 fibroblasts (Backstrom et al. 2000). A similar approach has indicated the $5-\mathrm{HT}_{2 \mathrm{~B}} \mathrm{R} \mathrm{PDZ}$ ligand is essential for receptor-mediated activation of constitutive and inducible NOS activities in a murine cell line (Manivet et al. 2000). The interaction of 5- $\mathrm{HT}_{2} \mathrm{Rs}$ (probably 5- $\mathrm{HT}_{2 \mathrm{~A}} \mathrm{Rs}$ ) with PDZ proteins may also be involved in the persistent facilitation of sensory synaptic transmission in the spinal cord dorsal horn, a process underlying chronic pain, 
following tissue injury ( $\mathrm{Li}$ and Zhuo 1998). This facilitation results from the mobilization of AMPA receptors into the synapses, transforming silent synapses into functional ones ( $\mathrm{Li}$ and Zhuo 1998). The recruitment of synaptic AMPA receptors induced by 5- $\mathrm{HT}_{2}$ agonists requires $\mathrm{PDZ}$ proteins that physically interact with GluR $2 / 3$ AMPA receptor subunits (Li et al. 1999). Thus, 5-HT2 and AMPA receptors appear to be functionally linked by a PDZ-based protein scaffold, contributing to the facilitation of nociceptive transmission in the spinal cord. The molecular composition of this PDZ scaffold is still unknown. Specific sets of PDZ proteins interacting with $5-\mathrm{HT}_{4(\mathrm{a})} \mathrm{R}$ and $5-\mathrm{HT}_{4(\mathrm{e})} \mathrm{R}$ have also been characterized by proteomic screens (Joubert et al. 2004). Among the 5-HT $\mathrm{H}_{4(\mathrm{a})} \mathrm{R}$ PDZbinding partners, NHERF-1 (also designated as Ezrinradixin- moesin-binding phosphoprotein 50, EBP50) and SNX27, a recently cloned sorting nexin, have attracted particular attention. Interaction of the $5-\mathrm{HT}_{4(\mathrm{a})} \mathrm{R}$ with NHERF-1 targets the receptor to specialized subcellular microdomains and seems to be involved in receptormediated cytoskeleton remodeling and the modulation of cell shape (Joubert et al. 2004). SNX27 belongs to a large protein family involved in the targeting of cell surface receptors to the endocytic compartment. The 5-HT ${ }_{4(\mathrm{a})} \mathrm{R} / \mathrm{SNX} 27$ interaction has been consistently found to target part of the receptor pool to early endosomes in heterologous cells (Joubert et al. 2004). Two forms of SNX27 that differ in their C-termini (designated as SNX27a and b) have been identified. Both proteins interact with the 5-HT ${ }_{4(\mathrm{a})} \mathrm{R}$ C-terminus and are enriched in the brain. SNX27b, but not SNX27a, has been found to be up-regulated in the neocortex of rats following acute exposure to psychostimulants, such as amphetamines and cocaine (Kajii et al. 2003). This up-regulation, blocked by D1 receptor antagonists, is reminiscent of stimulant-induced behavioral sensitization and therefore may be involved in the initiation and/or maintenance of long-term neuronal adaptation in response to psychostimulant compounds. As 5-HT $\mathrm{HT}_{4} \mathrm{Rs}$ have been involved in drug sensitization and addiction (Compan et al. 2004), the $5-\mathrm{HT}_{4} \mathrm{R} / \mathrm{SNX} 27$ interaction may contribute to neuronal adaptation mechanisms underlying these processes.

\subsubsection{Other proteins interacting with 5-HTR C-termini}

Several 5-HTR subtypes have been shown to interact physically with calmodulin (CaM) via their Cterminus (5- $\mathrm{HT}_{2 \mathrm{~A}} \mathrm{R}$ and 5-HT $\mathrm{H}_{2 \mathrm{C}} \mathrm{R}$; Becamel et al. 2002; Turner and Raymond 2005) and/or their intracellular loops (5-HT ${ }_{1 \mathrm{~A}} \mathrm{R}$ and 5- $\mathrm{HT}_{2 \mathrm{~A}} \mathrm{R}$; Turner et al. 2004; Turner and Raymond 2005). Putative CaM-binding sites have also been identified by using a CaM-binding site search engine (http://calcium. uhnres.utoronto.ca/ctdb/pub_pages/search/index.htm) for the intracellular loops of 5-HT 1 B , 5-HT 1 , 5 $\mathrm{HT}_{1 \mathrm{E}}, 5-\mathrm{HT}_{1 \mathrm{~F}}, 5-\mathrm{HT}_{2 \mathrm{C}}, 5-\mathrm{HT}_{6}$, and 5- $\mathrm{HT}_{7}$ receptors and in the C-terminus of 5- $\mathrm{HT}_{4}$ and 5- $\mathrm{HT}_{7}$ receptors (Turner and Raymond 2005), but these interactions remain to be established. The 5- $\mathrm{HT}_{2 \mathrm{~A}} \mathrm{R}$ C-terminal CaM-binding site, located at the juxtamembrane region, overlaps with a putative PKC phosphorylation site. CaM binding and receptor phosphorylation by PKC in vitro have been found to be antagonistic. This suggests that the interaction of $\mathrm{CaM}$ with the $5-\mathrm{HT}_{2 \mathrm{~A}} \mathrm{R}$ C-terminus can modulate receptor 
phosphorylation and desensitization (Turner and Raymond 2005). The 5- $\mathrm{HT}_{2 \mathrm{~A}} \mathrm{R}$ C-terminus also interacts with ARF1 and, to a lesser extent, ARF6 (Robertson et al. 2003). ARF proteins bind to a conserved NPxxY motif that has been found in a number of rhodopsin family GPCRs and that is located at the junction of the transmembrane domain 7 and the C-terminal domain (Johnson et al. 2006). This motif is critical in determining selective interaction with isoforms of ARF (Johnson et al. 2006). The interaction between $5-\mathrm{HT}_{2 \mathrm{~A}} \mathrm{R}$ and $\mathrm{ARF}$ proteins appears to be essential for $5-\mathrm{HT}_{2 \mathrm{~A}} \mathrm{R}$-mediated PLD activation, which is independent of $\mathrm{G} \alpha_{\mathrm{q} / 11}$ (Robertson et al. 2003). A weaker interaction between ARF16 and the i3 loop of the receptor has also been demonstrated. In addition to PDZ proteins and CaM, the 5- $\mathrm{HT}_{2} \mathrm{R}$ C-terminal domain recruits two other proteins with unknown functions: PTD4, a putative GTPbinding protein, and PICOT, a novel PKC theta-interacting protein with a thioredoxin homology domain that is involved in the regulation of the thioredoxin system (Becamel et al. 2002). The 5-HT $\mathrm{H}_{4(\mathrm{a})} \mathrm{R}$ associates with CRMP2, a member of the collapsin response mediator protein (CRMP) family, essential components of the molecular machinery leading to growth cone collapse in response to semaphorins. CRMP2 induces the outgrowth of multiple axons with a collapse of all dendrites in hippocampal neurons in vitro, thereby promoting neuronal polarity (Inagaki et al. 2001). $5-\mathrm{HT}_{4(\mathrm{a})} \mathrm{Rs}$ have been shown to cause $\mathrm{G}_{13^{-}}$and RhoA-dependent neurite retraction and cell rounding in neuroblastoma $\mathrm{x}$ glioma NIE-115 cells (Ponimaskin et al. 2002). Whether the physical interaction between 5-HT $\mathrm{H}_{4 \mathrm{a})} \mathrm{R}$ and CRMP2 contributes to the receptor regulation of neuronal architecture remains to be elucidated. Sec23A, a component of the COPII complex involved in the transport of secretory and plasma membrane proteins from the endoplasmic reticulum to the Golgi apparatus, has been found to associate with the 5-HT $4\left(\mathrm{e}_{\mathrm{e}} \mathrm{R}\right.$ C-terminus (Joubert et al. 2004). This interaction is inhibited by the deletion of the four C-terminal residues of the receptor, indicating a critical role of the extreme Cterminal sequence in the trafficking of short $5-\mathrm{HT}_{4} \mathrm{R}$ variants from the endoplasmic reticulum to the plasma membrane.

\subsection{Proteins interacting with the intracellular loops of 5-HTRs}

As previously mentioned, CaM-binding sites have been identified in the intracellular loops of several 5HTR subtypes. CaM has been shown to interact with two distinct motifs located in the $\mathrm{N}$ - and $\mathrm{C}$-termini juxtamembrane regions of the $5-\mathrm{HT}_{1 \mathrm{~A}} \mathrm{R} \mathrm{i}_{3}$ loop (Turner et al. 2004). Binding of $\mathrm{CaM}$ to $5-\mathrm{HT}_{1 \mathrm{~A}} \mathrm{R}$ has been found to be antagonistic with PKC-mediated receptor phosphorylation, suggesting a role in receptor desensitization. This interaction may also be critical for the 5- $\mathrm{HT}_{1 \mathrm{~A}} \mathrm{R}$-mediated activation of the ERK signaling pathway, a process involving agonist-induced receptor internalization (Della Rocca et al. 1999). Interaction of CaM with the $\mathrm{i}_{2}$ loop of $5-\mathrm{HT}_{2 \mathrm{~A}} \mathrm{Rs}$ decreases receptor-mediated $\left[{ }^{35} \mathrm{~S}\right] \mathrm{GTP} \gamma \mathrm{s}$ binding to NIH-3T3 cell membranes, suggesting a inhibitory role of $\mathrm{CaM}$ in 5-HT ${ }_{2 \mathrm{~A}} \mathrm{R}$-mediated signal transduction by dampening the interaction with the G protein (Turner and Raymond 2005). 5-HT $\mathrm{HA}_{\mathrm{A}} \mathrm{Rs}$ interact (via their intracellular loops) with other proteins that influence receptor subcellular distribution within neurons or modulate their signal transduction properties. These include the cytoskeletal 
microtubuleassociated protein MAP1A, caveolin-1, and the p90 ribosomal S6 kinase 2 (RSK2). The association of 5- $\mathrm{HT}_{2 \mathrm{~A}} \mathrm{Rs}$ ( $\mathrm{i}_{3}$ loop) with MAP1A may be responsible for the intracellular distribution of $5-\mathrm{HT}_{2 \mathrm{~A}} \mathrm{Rs}$ (in an inactive state) in the dendritic compartment of pyramidal neurons of the cerebral cortex (Cornea-Hebert et al. 2002). The 5- $\mathrm{HT}_{2 \mathrm{~A}} \mathrm{R} /$ caveolin-1 interaction, which has been observed in both $\mathrm{C} 6$ glioma cells and rat brain synaptic membrane preparations, appears to be essential for targeting the receptor to lipid rafts. This interaction facilitates $5-\mathrm{HT}_{2 \mathrm{~A}} \mathrm{R}$ coupling to Gaq proteins (Bhatnagar et al. 2004) and appears to be essential for the serotonin-induced inhibition of voltage-gated $\mathrm{K}^{+}$channels (Kv1.5), which form a ternary complex with 5- $\mathrm{HT}_{2 \mathrm{~A}} \mathrm{Rs}$ and caveolin-1 upon $5-\mathrm{HT}_{2 \mathrm{~A}} \mathrm{R}$ activation in smooth muscle cells of the pulmonary artery (Cogolludo et al. 2006). In contrast, the association of 5$\mathrm{HT}_{2 \mathrm{~A}} \mathrm{Rs}$ ( $\mathrm{i}_{3}$ loop) with RSK2 seems to be required for the tonic inhibition of receptor signaling exerted by this kinase (Sheffler et al. 2006). This tonic inhibition may result from constitutive receptor phosphorylation leading to a constitutively desensitized state. RSK2 expresses a C-terminal class I PDZ ligand (TAL), and RSK2/PDZ protein interactions have been demonstrated to be important for RSK2mediated modulation of excitatory synaptic transmission. This offers the possibility that $5-\mathrm{HT}_{2 \mathrm{~A}} \mathrm{R}$, RSK2, and PDZ proteins form a unique signaling complex modulating 5- $\mathrm{HT}_{2 \mathrm{~A}} \mathrm{R}$ function. In fetal myoblasts, serotonin induces a physical association of the 5-HT2A receptor with Jak2, providing a way of recruiting STAT3 by the receptor-kinase complex and the subsequent phosphorylation and nuclear translocation of STAT3 (Guillet-Deniau et al. 1997). The binding site of Jak2/STAT3 on the receptor (intracellular loops versus the C-terminus) is still uncertain. Activation of members the JAK/STAT pathway upon 5- $\mathrm{HT}_{2 \mathrm{~A}} \mathrm{R}$ activation has also been reported in vascular smooth muscle (Banes et al. 2005), but whether their physical association with the receptor is required for this activation remains to be demonstrated. A recent study has revealed that 5-HTRs are not only capable of interacting with protein kinases, but that they can also associate with phosphatases, modulating their phosphorylation state. This study has demonstrated a physical interaction between the $5-\mathrm{HT}_{2 \mathrm{C}} \mathrm{R} \mathrm{i}_{3}$ loop and the tumor suppressor PTEN, an enzyme exhibiting both lipid and protein phosphatase activities (Ji et al. 2006). This interaction takes place in dopaminergic neurons of the VTA innervating the accumbens nucleus, these are tonically inhibited by active $5-\mathrm{HT}_{2 \mathrm{C}} \mathrm{Rs}$. PTEN coupling with $5-\mathrm{HT}_{2 \mathrm{C}} \mathrm{Rs}$ prevents agonist-induced receptor phosphorylation at C-terminal serine residues. Disruption of the 5- $\mathrm{HT}_{2 \mathrm{C}} \mathrm{R} / \mathrm{PTEN}$ interaction with a membrane-permeant peptidyl mimetic of the PTEN-binding site consistently reproduces the inhibitory effect of 5-HT $2 \mathrm{C}$ agonists on VTA dopamine neuron firing. Such a peptide also prevents the rewarding effects of cannabinoids, effects that are mediated by the increased activity of VTA dopamine neurons, without the apparent side-effects observed following agonist activation of $5-\mathrm{HT}_{2} \mathrm{C}$. These experiments indicate that the regulation of $5-\mathrm{HT}_{2 \mathrm{C}} \mathrm{R}$ functional activity mediated by the interaction with PTEN plays an important role in the reinforcing role of drugs (Ji et al. 2006). Another recent study has reported the interaction of the third intracellular loop of 5-HT ${ }_{1 \mathrm{~B}} \mathrm{Rs}$ with p11 (also called S100A10 or calpactin I light chain or annexin II light chain), a member of the S100 EF-hand protein family (Svenningsson et al. 2006). This interaction enhances $5-\mathrm{HT}_{1 \mathrm{~B}} \mathrm{R}$ signaling efficacy by promoting its 
expression at the cell surface. Several pieces of evidence suggest that the dysfunction of $5-\mathrm{HT}_{1 \mathrm{~B}} \mathrm{R}$ regulation by p11 might be involved in depressive states: (1) p11 brain expression is increased by antidepressant treatments, whereas the level of the protein is reduced in an animal model of depression and in the brain of depressed patients; (2) p11 overexpression reproduces some behavior triggered by antidepressants in mice, and (3) p11 knock-out mice exhibit a depression-like syndrome and reduced responsiveness to antidepressant treatments (Svenningsson et al. 2006). These last-mentioned examples highlight the essential role of 5-HTR/accessory protein interactions in physiology and pathology and the potential of therapeutic strategies aimed at developing drugs capable of disrupting or reinforcing these interactions and exhibiting fewer side-effects than classical agonist- or antagonist-based treatments.

\section{Concluding remarks}

Metabotropic 5-HTRs are directly or indirectly the site of action of the most important drugs used to treat widely expressed psychiatric diseases such as depression, schizophrenia, and obsessive-compulsive behaviors. They are also the direct or indirect site of action of several important drugs of abuse such as cocaine and LSD. Finally, they play an essential role in cognition. Therefore, we need increase our knowledge of the 5-HTRs themselves, their signal transduction properties in neuronal cells, their role in synaptic plasticity, and the functional consequences of their interaction with accessory proteins. We have seen in this review that many questions remain to be addressed. With respect to 5-HTR-associated proteins, recent studies have clearly established their important functional and perhaps physiological roles (Bockaert et al. 2004b; Ji et al. 2006; Svenningsson et al. 2006). We are confident that pharmacological agents and perhaps drug targeting will clarify these interactions.

\section{References}

Adell A, Castro E, Celada P, Bortolozzi A, Pazos A, Artigas F (2005) Strategies for producing faster acting antidepressants. Drug Discov Today 10:578-585

Aghajanian GK, Marek GJ(1999a) Serotonin, via 5-HT2A receptors, increases EPSCs in layer V pyramidal cells of prefrontal cortex by an asynchronous mode of glutamate release. Brain Res 825:161-171

Aghajanian GK, Marek GJ(1999b) Serotonin and hallucinogens. Neuropsychopharmacology 21:16S$23 \mathrm{~S}$

Albert PR, Sajedi N, Lemonde S, Ghahremani MH (1999) Constitutive G(i2)-dependent activation of adenylyl cyclase type II by the 5-HT1A receptor. Inhibition by anxiolytic partial agonists. J Biol Chem 274:35469-35474

Andrade R, Chaput Y(1991) 5-Hydroxytryptamine4 receptors mediate the slow excitatory response to serotonin in the rat hippocampus. J Pharmacol Exp Ther 257:930-937

Andrade R, Malenka RC, Nicoll RA (1986) A G protein couples serotonin and GABAB receptors to the same channels in hippocampus. Science 234:1261-1265 
Ansanay H, Sebben M, Bockaert J, Dumuis A (1992) Characterization of homologous 5hydroxytryptamine4 receptor desensitization in colliculi neurons. Mol Pharmacol 42:808-816

Ansanay H, Dumuis A, Sebben M, Bockaert J, Fagni L (1995) A cyclic AMP-dependent, long-lasting inhibition of a K+ current in mammalian neurons. Proc Natl Acad Sci USA 92:6635-6639

Arvanov VL, Liang X, Russo A, Wang RY (1999) LSD and DOB: interaction with 5-HT2A receptors to inhibit NMDA receptormediated transmission in the rat prefrontal cortex. Eur J Neurosci 11:3064-3072

Backstrom JR, Price RD, Reasoner DT, Sanders-Bush E (2000) Deletion of the serotonin 5-HT2C receptor PDZ recognition motif prevents receptor phosphorylation and delays resensitization of receptor responses. J Biol Chem 275:23620-23626

Banes AK, Shaw SM, Tawfik A, Patel BP, Ogbi S, Fulton D, Marrero MB (2005) Activation of the JAK/STAT pathway in vascular smooth muscle by serotonin. Am J Physiol Cell Physiol 288: C805-C812

Barnes NM, Sharp T (1999) A review of central 5-HT receptors and their function. Neuropharmacology 38:1083-1152

Barthet G, Gaven F, Framery B, Shinjo K, Nakamura T, Claeysen S, Bockaert J, Dumuis A (2005) Uncoupling and endocytosis of 5-hydroxytryptamine 4 receptors. Distinct molecular events with different GRK2 requirements. J Biol Chem 280: 27924-27934

Becamel C, Figge A, Poliak S, Dumuis A, Peles E, Bockaert J, Lubbert H, Ullmer C (2001) Interaction of serotonin 5-hydroxytryptamine type $2 \mathrm{C}$ receptors with PDZ10 of the multi-PDZ domain protein MUPP1. J Biol Chem 276:12974-12982

Becamel C, Alonso G, Galeotti N, Demey E, Jouin P, Ullmer C, Dumuis A, Bockaert J, Marin P (2002) Synaptic multiprotein complexes associated with 5-HT(2C) receptors: a proteomic approach. EMBO J 21:2332-2342

Becamel C, Gavarini S, Chanrion B, Alonso G, Galeotti N, Dumuis A, Bockaert J, Marin P (2004) The serotonin 5-HT2A and 5-HT2C receptors interact with specific sets of PDZ proteins. J Biol Chem 279:20257-20266

Bender E, Pindon A, Oers I van, Zhang YB, Gommeren W, Verhasselt P, Jurzak M, Leysen J, Luyten W (2000) Structure of the human serotonin 5-HT4 receptor gene and cloning of a novel 5-HT4 splice variant. J Neurochem 74:478-489

Berg KA, Harvey JA, Spampinato U, Clarke WP (2005) Physiological relevance of constitutive activity of 5-HT2A and 5-HT2C receptors. Trends Pharmacol Sci 26:625-630

Bhatnagar A, Sheffler DJ, Kroeze WK, Compton-Toth B, Roth BL (2004) Caveolin-1 interacts with 5HT2A serotonin receptors and profoundly modulates the signaling of selected Galphaq-coupled protein receptors. J Biol Chem 279:34614-34623

Bickmeyer U, Heine M, Manzke T, Richter DW (2002) Differential modulation of I(h) by 5-HT receptors in mouse CA1 hippocampal neurons. Eur J Neurosci 16:209-218

Bockaert J, Dumuis A (1998) Localization of 5-HT4 receptors in vertebrate brain and their potential roles. Springer, Palo Alto

Bockaert J, Sebben M, Dumuis A (1990) Pharmacological characterization of 5-HT4 receptors positively coupled to adenylate cyclase in adult guinea pig hippocampal membranes: effect of substituted benzamide derivatives. Mol Pharmacol 37:408-411

Bockaert J, Fagni L, Dumuis A (1997) 5-HT4 receptors: an update. In: Baumgarten HG, Göthert M (eds) Handbook of experimental pharmacology: serotoninergic neurons and 5-HT receptors in the CNS. Springer, Berlin Heidelberg New York, pp 439-465

Bockaert J, Marin P, Dumuis A, Fagni L (2003) The "magic tail" of G protein-coupled receptors: an anchorage for functional protein networks. FEBS Lett 546:65-72 
Bockaert J, Claeysen S, Compan V, Dumuis A (2004a) 5-HT4 receptors. Curr Drug Targets CNS Neurol Disord 3:39-51

Bockaert J, Roussignol G, Becamel C, Gavarini S, Joubert L, Dumuis A, Fagni L, Marin P (2004b) GPCR-interacting proteins (GIPs): nature and functions. Biochem Soc Trans 32:851-855

Bockaert J, Claeysen S, Joubert L, Fagni L, Dumuis A (2005) Molecular and cellular determinants of GPCR splice variant constitutive activity. Wiley-VCH, New York

Borg J, Andree B, Soderstrom H, Farde L (2003) The serotonin system and spiritual experiences. Am J Psychiatry 160:1965-1969

Bouhelal R, Smounya L, Bockaert J (1988) 5-HT1B receptors are negatively coupled with adenylate cyclase in rat substantia nigra. Eur J Pharmacol 151:189-196

Brailov I, Bancila M, Brisorgueil MJ, Miquel MC, Hamon M, Verge D (2000) Localization of 5-HT(6) receptors at the plasma membrane of neuronal cilia in the rat brain. Brain Res 872:271-275

Brattelid T, Kvingedal AM, Krobert KA, Andressen KW, Bach T, Hystad ME, Kaumann AJ, Levy FO (2004) Cloning, pharmacological characterisation and tissue distribution of a novel 5-HT4 receptor splice variant, 5-HT4(i). Naunyn-Schmiedeberg's Arch Pharmacol 369:616-628

Brezun JM, Daszuta A (1999) Depletion in serotonin decreases neurogenesis in the dentate gyrus and the subventricular zone of adult rats. Neuroscience 89:999-1002

Burns CM, Chu H, Rueter SM, Hutchinson LK, Canton H, Sanders- Bush E, Emeson RB (1997) Regulation of serotonin-2C receptor G-protein coupling by RNA editing. Nature 387:303-308

Cai X, Flores-Hernandez J, Feng J, Yan Z (2002) Activity-dependent bidirectional regulation of GABA(A) receptor channels by the 5-HT(4) receptor-mediated signalling in rat prefrontal cortical pyramidal neurons. J Physiol (Lond) 540:743-759

Cardenas CG, Del Mar LP, Scroggs RS (1997) Two parallel signaling pathways couple 5HT1A receptors to $\mathrm{N}$ - and L-type calcium channels in C-like rat dorsal root ganglion cells. $\mathrm{J}$ Neurophysiol 77:3284-3296

Carr DB, Cooper DC, Ulrich SL, Spruston N, Surmeier DJ (2002) Serotonin receptor activation inhibits sodium current and dendritic excitability in prefrontal cortex via a protein kinase C-dependent mechanism. J Neurosci 22:6846-6855

Chang M, Zhang L, Tam JP, Sanders-Bush E (2000) Dissecting G protein-coupled receptor signaling pathways with membranepermeable blocking peptides. Endogenous 5-HT(2C) receptors in choroid plexus epithelial cells. J Biol Chem 275:7021-7029

Claeysen S, Sebben M, Becamel C, Bockaert J, Dumuis A (1999) Novel brain-specific 5-HT4 receptor splice variants show marked constitutive activity: role of the C-terminal intracellular domain. Mol Pharmacol 55:910-920

Cogolludo A, Moreno L, Lodi F, Frazziano G, Cobeno L, Tamargo J, Perez-Vizcaino F (2006) Serotonin inhibits voltage-gated $\mathrm{K}+$ currents in pulmonary artery smooth muscle cells. Role of 5- HT2A receptors, caveolin-1, and KV1.5 channel internalization. Circ Res (in press)

Collier HOJ (1958) The occurrence of 5-hydroxytryptamine (5-HT) in nature. Pergamon, New York

Compan V, Zhou M, Grailhe R, Gazzara RA, Martin R, Gingrich J, Dumuis A, Brunner D, Bockaert J, Hen R (2004) Attenuated response to stress and novelty and hypersensitivity to seizures in 5-HT4 receptor knock-out mice. J Neurosci 24:412-419

Cornea-Hebert V, Riad M, Wu C, Singh SK, Descarries L (1999) Cellular and subcellular distribution of the serotonin 5-HT2A receptor in the central nervous system of adult rat. J Comp Neurol 409:187-209 
Cornea-Hebert V, Watkins KC, Roth BL, Kroeze WK, Gaudreau P, Leclerc N, Descarries L (2002) Similar ultrastructural distribution of the 5-HT(2A) serotonin receptor and microtubuleassociated protein MAP1A in cortical dendrites of adult rat. Neuroscience 113:23-35

Day M, Olson PA, Platzer J, Striessnig J, Surmeier DJ (2002) Stimulation of 5-HT(2) receptors in prefrontal pyramidal neurons inhibits $\mathrm{Ca}(\mathrm{v}) 1.2 \mathrm{~L}$ type $\mathrm{Ca}(2+)$ currents via a PLCbeta/IP3/ calcineurin signaling cascade. J Neurophysiol 87:2490-2504

De Deurwaerdere P, Navailles S, Berg KA, Clarke WP, Spampinato U (2004) Constitutive activity of the serotonin $2 \mathrm{C}$ receptor inhibits in vivo dopamine release in the rat striatum and nucleus accumbens. J Neurosci 24:3235-3241

De Vivo M, Maayani S (1986) Characterization of the 5-hydroxytryptamine1A receptor-mediated inhibition of forskolin-stimulated adenylate cyclase activity in guinea pig and rat hippocampal membranes. J Pharmacol Exp Ther 238:248-253

Della Rocca GJ, Mukhin YV, Garnovskaya MN, Daaka Y, Clark GJ, Luttrell LM, Lefkowitz RJ, Raymond JR (1999) Serotonin 5- HT1A receptor-mediated Erk activation requires calcium/calmodulin- dependent receptor endocytosis. J Biol Chem 274:4749-4753

Descarries L, Beaudet A, Watkins KC (1975) Serotonin nerve terminals in adult rat neocortex. Brain Res 100:563-588

Di Matteo V, De Blasi A, Di Giulio C, Esposito E (2001) Role of 5- HT(2C) receptors in the control of central dopamine function. Trends Pharmacol Sci 22:229-232

Dumuis A, Bouhelal R, Sebben M, Cory R, Bockaert J (1988) A nonclassical 5-hydroxytryptamine receptor positively coupled with adenylate cyclase in the central nervous system. Mol Pharmacol 34:880-887

Edagawa Y, Saito H, Abe K (1998) 5-HT1A receptor-mediated inhibition of long-term potentiation in rat visual cortex. Eur J Pharmacol 349:221-224

Egan CT, Herrick-Davis K, Teitler M (1998) Creation of a constitutively activated state of the 5hydroxytryptamine2A receptor by site-directed mutagenesis: inverse agonist activity of antipsychotic drugs. J Pharmacol Exp Ther 286:85-90

Erspamer V, Asero B (1952) Identification of enteramine, the specific hormone of the enterochromaffin cell system, as 5-hydroxytryptamine. Nature 169:800-801

Fabre V, Beaufour C, Evrard A, Rioux A, Hanoun N, Lesch KP, Murphy DL, Lanfumey L, Hamon M, Martres MP (2000) Altered expression and functions of serotonin 5-HT1A and 5- HT1B receptors in knock-out mice lacking the 5-HT transporter. Eur J Neurosci 12:2299-2310

Fagni L, Dumuis A, Sebben M, Bockaert J (1992) The 5-HT4 receptor subtype inhibits K+ current in colliculi neurons via activation of a cyclic AMP-dependent protein kinase. Br J Pharmacol 105:973-979

Fitzgerald LW, Iyer G, Conklin DS, Krause CM, Marshall A, Patterson JP, Tran DP, Jonak GJ, Hartig PR (1999) Messenger RNA editing of the human serotonin 5-HT2C receptor. Neuropsychopharmacology 21:82S-90S

Gaspar P, Cases O, Maroteaux L (2003) The developmental role of serotonin: news from mouse molecular genetics. Nat Rev Neurosci 4:1002-1012

Gerard C, Martres MP, Lefevre K, Miquel MC, Verge D, Lanfumey L, Doucet E, Hamon M, Mestikawy $\mathrm{S}$ el (1997) Immuno-localization of serotonin 5-HT6 receptor-like material in the rat central nervous system. Brain Res 746:207-219

Gingrich JA, Hen R (2001) Dissecting the role of the serotonin system in neuropsychiatric disorders using knockout mice. Psychopharmacology (Berl) 155:1-10

Goaillard JM, Vincent P (2002) Serotonin suppresses the slow afterhyperpolarization in rat intralaminar and midline thalamic neurones by activating 5-HT(7) receptors. J Physiol (Lond) 541:453-465 
Gobert A, Rivet JM, Lejeune F, Newman-Tancredi A, Adhumeau- Auclair A, Nicolas JP, Cistarelli L, Melon C, Millan MJ (2000) Serotonin(2C) receptors tonically suppress the activity of mesocortical dopaminergic and adrenergic, but not serotonergic, pathways: a combined dialysis and electrophysiological analysis in the rat. Synapse 36:205-221

Gross C, Hen R (2004) The developmental origins of anxiety. Nat Rev Neurosci 5:545-552

Guillet-Deniau I, Burnol AF, Girard J (1997) Identification and localization of a skeletal muscle secrotonin 5-HT2A receptor coupled to the Jak/STAT pathway. J Biol Chem 272:14825-14829

Gurevich I, Englander MT, Adlersberg M, Siegal NB, Schmauss C (2002a) Modulation of serotonin 2C receptor editing by sustained changes in serotonergic neurotransmission. J Neurosci 22:1052910532

Gurevich I, Tamir H, Arango V, Dwork AJ, Mann JJ, Schmauss C (2002b) Altered editing of serotonin $2 \mathrm{C}$ receptor pre-mRNA in the prefrontal cortex of depressed suicide victims. Neuron 34:349-356

Harvey JA (2003) Role of the serotonin 5-HT(2A) receptor in learning. Learn Mem 10:355-362

Hedlund PB, Sutcliffe JG (2004) Functional, molecular and pharmacological advances in 5-HT7 receptor research. Trends Pharmacol Sci 25:481-486

Heidmann DE, Metcalf MA, Kohen R, Hamblin MW (1997) Four 5- hydroxytryptamine7 (5-HT7) receptor isoforms in human and rat produced by alternative splicing: species differences due to altered intron-exon organization. J Neurochem 68:1372-1381

Higuchi M, Single FN, Kohler M, Sommer B, Sprengel R, Seeburg PH (1993) RNA editing of AMPA receptor subunit GluR-B: a base-paired intron-exon structure determines position and efficiency. Cell 75:1361-1370

Hiroi T, Hayashi-Kobayashi N, Nagumo S, Ino M, Okawa Y, Aoba A, Matsui H (2001) Identification and characterization of the human serotonin- 4 receptor gene promoter. Biochem Biophys Res Commun 289:337-344

Hori Y, Endo K, Takahashi T (1996) Long-lasting synaptic facilitation induced by serotonin in superficial dorsal horn neurones of the rat spinal cord. J Physiol (Lond) 492:867-876

Hoyer D, Martin G (1997) 5-HT receptor classification and nomenclature: towards a harmonization with human genome. Neuropharmacology, 36:419-428

Inagaki N, Chihara K, Arimura N, Menager C, Kawano Y, Matsuo N, Nishimura T, Amano M, Kaibuchi K (2001) CRMP-2 induces axons in cultured hippocampal neurons. Nat Neurosci 4:781-782

Jakab RL, Goldman-Rakic PS (1998) 5-Hydroxytryptamine2A serotonin receptors in the primate cerebral cortex: possible site of action of hallucinogenic and antipsychotic drugs in pyramidal cell apical dendrites. Proc Natl Acad Sci USA 95:735-740

Ji SP, Zhang Y, Van Cleemput J, Jiang W, Liao M, Li L, Wan Q, Backstrom JR, Zhang X (2006) Disruption of PTEN coupling with 5-HT2C receptors suppresses behavioral responses induced by drugs of abuse. Nat Med 12:324-329

Johnson MS, Robertson DN, Holland PJ, Lutz EM, Mitchell R (2006) Role of the conserved NPxxY motif of the 5-HT(2A) receptor in determining selective interaction with isoforms of ADPRibosylation Factor (ARF). Cell Signal (in press)

Joubert L, Hanson B, Barthet G, Sebben M, Claeysen S, Hong W, Marin P, Dumuis A, Bockaert J (2004) New sorting nexin (SNX27) and NHERF specifically interact with the 5-HT4a receptor splice variant: roles in receptor targeting. J Cell Sci 117:5367-5379

Kajii Y, Muraoka S, Hiraoka S, Fujiyama K, Umino A, Nishikawa T (2003) A developmentally regulated and psychostimulant-inducible novel rat gene mrtl encoding PDZ-PX proteins isolated in the neocortex. Mol Psychiatry 8:434-444 
Karschin A, Ho BY, Labarca C, Elroy-Stein O, Moss B, Davidson N, Lester HA (1991) Heterologously expressed serotonin 1A receptors couple to muscarinic K+ channels in heart. Proc Natl Acad Sci USA 88:5694-5698

Kemp A, Manahan-Vaughan D (2004) Hippocampal long-term depression and long-term potentiation encode different aspects of novelty acquisition. Proc Natl Acad Sci USA 101:8192-8197

Kemp A, Manahan-Vaughan D (2005) The 5-hydroxytryptamine4 receptor exhibits frequencydependent properties in synaptic plasticity and behavioural metaplasticity in the hippocampal CA1 region in vivo. Cereb Cortex 15:1037-1043

Kiel S, Bruss M, Bonisch H, Gothert M (2000) Pharmacological properties of the naturally occurring Phe-124-Cys variant of the human 5-HT1B receptor: changes in ligand binding, G-protein coupling and second messenger formation. Pharmacogenetics 10:655-666

Kilbinger H, Wolf D (1992) Effects of 5-HT4 receptor stimulation on basal and electrically evoked release of acetylcholine from guinea-pig myenteric plexus. Naunyn Schmiedebergs Arch Pharmacol 345:270-275

Kilbinger H, Gebauer A, Haas J, Ladinsky H, Rizzi CA (1995) Benzimidazolones and renzapride facilitate acetylcholine release from guinea-pig myenteric plexus via 5-HT4 receptors. Naunyn Schmiedebergs Arch Pharmacol 351:229-236

Kishore S, Stamm S (2006) The snoRNA HBII-52 regulates alternative splicing of the serotonin receptor 2C. Science 311:230-232

Kroeze WK, Roth BL (1998) The molecular biology of serotonin receptors: therapeutic implications for the interface of mood and psychosis. Biol Psychiatry 44:1128-1142

Kvachnina E, Liu G, Dityatev A, Renner U, Dumuis A, Richter DW, Dityateva G, Schachner M, VoynoYasenetskaya TA, Ponimaskin EG (2005) 5-HT7 receptor is coupled to Galpha subunits of heterotrimeric G12-protein to regulate gene transcription and neuronal morphology. J Neurosci 25:7821-7830

Lanfumey L, Hamon M (2004) 5-HT1 receptors. Curr Drug Targets CNS Neurol Disord 3:1-10

Lefkowitz RJ, Shenoy SK (2005) Transduction of receptor signals by beta-arrestins. Science 308:512517 Leysen JE (2004) 5-HT2 receptors. Curr Drug Targets CNS Neurol Disord 3:11-26

Lezoualc'h F, Robert SJ (2003) The serotonin 5-HT4 receptor and the amyloid precursor protein processing. Exp Gerontol 38:159-166

Li P, Zhuo M (1998) Silent glutamatergic synapses and nociception in mammalian spinal cord. Nature 393:695-698

Li P, Kerchner GA, Sala C, Wei F, Huettner JE, Sheng M, Zhuo M (1999) AMPA receptor-PDZ interactions in facilitation of spinal sensory synapses. Nat Neurosci 2:972-977

Lin SL, Johnson-Farley NN, Lubinsky DR, Cowen DS (2003) Coupling of neuronal 5-HT7 receptors to activation of extracellular-regulated kinase through a protein kinase A-independent pathway that can utilize Epac. J Neurochem 87:1076-1085

Liu M, Geddis MS, Wen Y, Setlik W, Gershon MD (2005) Expression and function of 5-HT4 receptors in the mouse enteric nervous system. Am J Physiol Gastrointest Liver Physiol 289:G1148-G1163

Lopez-Gimenez JF, Mengod G, Palacios JM, Vilaro MT (2001) Regional distribution and cellular localization of 5-HT2C receptor mRNA in monkey brain: comparison with $[3 \mathrm{H}]$ mesulergine binding sites and choline acetyltransferase mRNA. Synapse 42:12-26

Lucas G, Debonnel G (2002) 5-HT4 receptors exert a frequencyrelated facilitatory control on dorsal raphe nucleus 5-HT neuronal activity. Eur J Neurosci 16:817-822 
Lucas G, Compan V, Charnay Y, Neve RL, Nestler EJ, Bockaert J, Barrot M, Debonnel G (2005) Frontocortical 5-HT4 receptors exert positive feedback on serotonergic activity: viral transfections, subacute and chronic treatments with 5-HT4 agonists. Biol Psychiatry 57:918-925

Manivet P, Mouillet-Richard S, Callebert J, Nebigil CG, Maroteaux L, Hosoda S, Kellermann O, Launay JM (2000) PDZ-dependent activation of nitric-oxide synthases by the serotonin 2B receptor. J Biol Chem 275:9324-9331

Manzke T, Guenther U, Ponimaskin EG, Haller M, Dutschmann M, Schwarzacher S, Richter DW (2003) 5-HT4(a) receptors avert opioid-induced breathing depression without loss of analgesia. Science 301:226-229

Marek GJ, Aghajanian GK (1999) 5-HT2A receptor or alpha1- adrenoceptor activation induces excitatory postsynaptic currents in layer $\mathrm{V}$ pyramidal cells of the medial prefrontal cortex. Eur $\mathrm{J}$ Pharmacol 367:197-206

Marek GJ, Wright RA, Schoepp DD, Monn JA, Aghajanian GK (2000) Physiological antagonism between 5-hydroxytryptamine (2A) and group II metabotropic glutamate receptors in prefrontal cortex. J Pharmacol Exp Ther 292:76-87

Matsumoto M, Kojima T, Togashi H, Mori K, Ohashi S, Ueno K, Yoshioka M (2002) Differential characteristics of endogenous serotonin-mediated synaptic transmission in the hippocampal CA1 and CA3 fields of anaesthetized rats. Naunyn-Schmiedeberg's Arch Pharmacol 366:570-577

McGrew L, Chang MS, Sanders-Bush E (2002) Phospholipase D activation by endogenous 5hydroxytryptamine $2 \mathrm{C}$ receptors is mediated by Galpha13 and pertussis toxin-insensitive Gbetagamma subunits. Mol Pharmacol 62:1339-1343

McGrew L, Price RD, Hackler E, Chang MS, Sanders-Bush E (2004) RNA editing of the human serotonin 5-HT2C receptor disrupts transactivation of the small G-protein RhoA. Mol Pharmacol $65: 252-256$

Miller KJ (2005) Serotonin 5-ht2c receptor agonists: potential for the treatment of obesity. Mol Interv 5:282-291

Miner LA, Backstrom JR, Sanders-Bush E, Sesack SR (2003) Ultrastructural localization of serotonin2A receptors in the middle layers of the rat prelimbic prefrontal cortex. Neuroscience 116:107-117

Nelson DL (2004) 5-HT5 receptors. Curr Drug Targets CNS Neurol Disord 3:53-58

Niesler B, Frank B, Kapeller J, Rappold GA (2003) Cloning, physical mapping and expression analysis of the human 5-HT3 serotonin receptor-like genes HTR3C, HTR3D and HTR3E. Gene 310:101111

Niswender CM, Copeland SC, Herrick-Davis K, Emeson RB, Sanders-Bush E (1999) RNA editing of the human serotonin 5- hydroxytryptamine $2 \mathrm{C}$ receptor silences constitutive activity. J Biol Chem 274:9472-9478

Noda M, Yasuda S, Okada M, Higashida H, Shimada A, Iwata N, Ozaki N, Nishikawa K, Shirasawa S, Uchida M, Aoki S, Wada K (2003) Recombinant human serotonin 5A receptors stably expressed in C6 glioma cells couple to multiple signal transduction pathways. J Neurochem 84:222-232

Norum JH, Hart K, Levy FO (2003) Ras-dependent ERK activation by the human G(s)-coupled serotonin receptors 5-HT4(b) and 5- HT7(a). J Biol Chem 278:3098-3104

Nourry C, Grant SG, Borg JP (2003) PDZ domain proteins: plug and play! Sci STKE 2003:RE7

Oleskevich S (1995) G alpha o1 decapeptide modulates the hippocampal 5-HT1A potassium current. J Neurophysiol 74:2189-2193

Olsen MA, Nawoschik SP, Schurman BR, Schmitt HL, Burno M, Smith DL, Schechter LE (1999) Identification of a human 5-HT6 receptor variant produced by alternative splicing. Brain Res Mol Brain Res 64:255-263 
Parker LL, Backstrom JR, Sanders-Bush E, Shieh BH (2003) Agonistinduced phosphorylation of the serotonin 5-HT2C receptor regulates its interaction with multiple PDZ protein 1. J Biol Chem 278:21576-21583

Pauwels PJ (1997) 5-HT 1B/D receptor antagonists. Gen Pharmacol 29:293-303 Pehek EA, McFarlane HG, Maguschak K, Price B, Pluto CP (2001) M100,907, a selective 5-HT(2A) antagonist, attenuates dopamine release in the rat medial prefrontal cortex. Brain Res 888:51-59

Ponimaskin EG, Profirovic J, Vaiskunaite R, Richter DW, Voyno- Yasenetskaya TA (2002) 5Hydroxytryptamine 4(a) receptor is coupled to the Galpha subunit of heterotrimeric G13 protein. J Biol Chem 277:20812-20819

Price RD, Weiner DM, Chang MS, Sanders-Bush E (2001) RNA editing of the human serotonin 5HT2C receptor alters receptormediated activation of G13 protein. J Biol Chem 276:44663-44668

Rapport MM, Green AA, Page IH (1948) Serum vasoconstrictor (serotonin). IV. Isolation and characterization. J Biol Chem 176:1243-1251

Raymond JR, Mukhin YV, Gelasco A, Turner J, Collinsworth G, Gettys TW, Grewal JS, Garnovskaya MN (2001) Multiplicity of mechanisms of serotonin receptor signal transduction. Pharmacol Ther 92:179-212

Rees S, Daas I den, Foord S, Goodson S, Bull D, Kilpatrick G, Lee M (1994) Cloning and characterisation of the human 5-HT5A serotonin receptor. FEBS Lett 355:242-246

Riad M, Garcia S, Watkins KC, Jodoin N, Doucet E, Langlois X, el Mestikawy S, Hamon M, Descarries L (2000) Somatodendritic localization of 5-HT1A and preterminal axonal localization of 5- HT1B serotonin receptors in adult rat brain. J Comp Neurol 417:181-194

Robertson DN, Johnson MS, Moggach LO, Holland PJ, Lutz EM, Mitchell R (2003) Selective interaction of ARF1 with the carboxy-terminal tail domain of the 5-HT2A receptor. Mol Pharmacol 64:1239-1250

Roth BL, Ciaranello RD (1991) Chronic mianserin treatment decreases 5-HT2 receptor binding without altering 5-HT2 receptor mRNA levels. Eur J Pharmacol 207:169-172

Ruat M, Traiffort E, Arrang JM, Tardivel-Lacombe J, Diaz J, Leurs R, Schwartz JC (1993) A novel rat serotonin (5-HT6) receptor: molecular cloning, localization and stimulation of cAMP accumulation. Biochem Biophys Res Commun 193:268-276

Sanden N, Thorlin T, Blomstrand F, Persson PA, Hansson E (2000) 5- Hydroxytryptamine2B receptors stimulate $\mathrm{Ca} 2+$ increases in cultured astrocytes from three different brain regions. Neurochem Int $36: 427-434$

Sanders-Bush E (1990) Adaptive regulation of central serotonin receptors linked to phosphoinositide hydrolysis. Neuropsychopharmacology 3:411-416

Sanders-Bush E, Breeding M (1988) Putative selective 5-HT-2 antagonists block serotonin 5-HT-1c receptors in the choroid plexus. J Pharmacol Exp Ther 247:169-173

Santarelli L, Saxe M, Gross C, Surget A, Battaglia F, Dulawa S, Weisstaub N, Lee J, Duman R, Arancio O, Belzung C, Hen R (2003) Requirement of hippocampal neurogenesis for the behavioral effects of antidepressants. Science 301:805-809

Sari Y, Lefevre K, Bancila M, Quignon M, Miquel MC, Langlois X, Hamon M, Verge D (1997) Light and electron microscopic immunocytochemical visualization of 5-HT1B receptors in the rat brain. Brain Res 760:281-286

Schlag BD, Lou Z, Fennell M, Dunlop J (2004) Ligand dependency of 5-hydroxytryptamine 2C receptor internalization. J Pharmacol Exp Ther 310:865-870

Schoeffter P, Waeber C (1994) 5-Hydroxytryptamine receptors with a 5-HT6 receptor-like profile stimulating adenylyl cyclase activity in pig caudate membranes. Naunyn-Schmiedeberg's Arch Pharmacol 350:356-360 
Sebben M, Ansanay H, Bockaert J, Dumuis A (1994) 5-HT6 receptors positively coupled to adenylyl cyclase in striatal neurones in culture. Neuroreport 5:2553-2557

Sheffler DJ, Kroeze WK, Garcia BG, Deutch AY, Hufeisen SJ, Leahy P, Bruning JC, Roth BL (2006) p90 ribosomal S6 kinase 2 exerts a tonic brake on $\mathrm{G}$ protein-coupled receptor signaling. Proc Natl Acad Sci USA 103:4717-4722

Sodickson DL, Bean BP (1998) Neurotransmitter activation of inwardly rectifying potassium current in dissociated hippocampal CA3 neurons: interactions among multiple receptors. J Neurosci 18:8153-8162

Sotelo C, Cholley B, El Mestikawy S, Gozlan H, Hamon M (1990) Direct immunohistochemical evidence of the existence of 5-HT1A autoreceptors on serotoninergic neurons in the midbrain raphe nuclei. Eur J Neurosci 2:1144-1154

Starke K, GothertM, Kilbinger H (1989)Modulation of neurotransmitter release by presynaptic autoreceptors. Physiol Rev 69:864-989

Svenningsson P, Chergui K, Rachleff I, Flajolet M, Zhang X, Yacoubi ME, Vaugeois JM, Nomikos GG, Greengard P (2006) Alterations in 5-HT1B receptor function by p11 in depression-like states. Science 311:77-80

Thomas DR, Hagan JJ (2004) 5-HT7 receptors. Curr Drug Targets CNS Neurol Disord 3:81-90 Torres GE, Arfken CL, Andrade R (1996) 5-Hydroxytryptamine4 receptors reduce afterhyperpolarization in hippocampus by inhibiting calcium-induced calcium release. Mol Pharmacol 50:1316-1322

Turner JH, Raymond JR (2005) Interaction of calmodulin with the serotonin 5-hydroxytryptamine2A receptor. A putative regulator of $\mathrm{G}$ protein coupling and receptor phosphorylation by protein kinase C. J Biol Chem 280:30741-30750

Turner JH, Gelasco AK, Raymond JR (2004) Calmodulin interacts with the third intracellular loop of the serotonin 5-hydroxytryptaminelA receptor at two distinct sites: putative role in receptor phosphorylation by protein kinase C. J Biol Chem 279:17027-17037

Ullmer C, Schmuck K, Figge A, Lubbert H (1998) Cloning and characterization of MUPP1, a novel PDZ domain protein. FEBS Lett 424:63-68

Van Hooft JA, Yakel JL (2003) 5-HT3 receptors in the CNS: 3B or not 3B? Trends Pharmacol Sci 24:157-160

Van Oekelen D, Luyten WH, Leysen JE (2003) 5-HT2A and 5-HT2C receptors and their atypical regulation properties. Life Sci 72:2429-2449

Villalobos C, Beique JC, Gingrich JA, Andrade R (2005) Serotonergic regulation of calcium-activated potassium currents in rodent prefrontal cortex. Eur J Neurosci 22:1120-1126

Wainscott DB, Cohen ML, Schenck KW, Audia JE, Nissen JS, Baez M, Kursar JD, Lucaites VL, Nelson DL (1993) Pharmacological characteristics of the newly cloned rat 5-hydroxytryptamine2F receptor. Mol Pharmacol 43:419-426

Weiss S, Pin J-P, Sebben M, Kemp D, Sladeczek F, Gabrion J, Bockaert J (1986) Synaptogenesis of cultured striatal neurones in serum-free medium: a morphological and biochemical study. Proc Natl Acad Sci USA 83:2238-2242

Williams GV, Rao SG, Goldman-Rakic PS (2002) The physiological role of 5-HT2A receptors in working memory. J Neurosci 22:2843-2854

Willins DL, Berry SA, Alsayegh L, Backstrom JR, Sanders-Bush E, Friedman L, Roth BL (1999) Clozapine and other 5-hydroxytryptamine- 2A receptor antagonists alter the subcellular distribution of 5-hydroxytryptamine-2A receptors in vitro and in vivo. Neuroscience 91:599-606

Woolley ML, Marsden CA, Fone KC (2004) 5-HT6 receptors. Curr Drug Targets CNS Neurol Disord 3:59-79 
Xia Z, Gray JA, Compton-Toth BA, Roth BL (2003a) A direct interaction of PSD95 with 5-HT2A serotonin receptors regulates receptor trafficking and signal transduction. J Biol Chem 278: 21901-21908

Xia Z, Hufeisen SJ, Gray JA, Roth BL (2003b) The PDZ-binding domain is essential for the dendritic targeting of 5-HT2A serotonin receptors in cortical pyramidal neurons in vitro. Neuroscience 122:907-920

Xie E, Zhu L, Zhao L, Chang LS (1996) The human serotonin 5-HT2C receptor: complete cDNA, genomic structure, and alternatively spliced variant. Genomics 35:551-561

Yan W, Wilson CC, Haring JH (1997) 5-HT1a receptors mediate the neurotrophic effect of serotonin on developing dentate granule cells. Brain Res Dev Brain Res 98:185-190

Yuen EY, Jiang Q, Chen P, Gu Z, Feng J, Yan Z (2005) Serotonin 5-HT1A receptors regulate NMDA receptor channels through a microtubule-dependent mechanism. J Neurosci 25:5488-5501

Zhou FM, Hablitz JJ (1999) Activation of serotonin receptors modulates synaptic transmission in rat cerebral cortex. J Neurophysiol 82:2989-2999 


\begin{tabular}{|c|c|c|c|c|}
\hline $\begin{array}{l}\text { Receptor } \\
\text { subtype }\end{array}$ & $\begin{array}{c}\text { Intracellular } \\
\text { loop }\end{array}$ & C-terminus & $\begin{array}{l}\text { Function of the identified } \\
\text { interaction }\end{array}$ & References \\
\hline $5-\mathrm{HT}_{1 \mathrm{~A}}$ & Calmodulin & & Trafficking, signaling & (Turner et al., 2004) \\
\hline $5-\mathrm{HT}_{1 \mathrm{~B}}$ & $\mathrm{p} 11$ & & $\begin{array}{l}\text { Increases receptor cell surface } \\
\text { expression and function }\end{array}$ & $\begin{array}{c}\text { (Svenningsson et al., } \\
\text { 2006) }\end{array}$ \\
\hline \multirow[t]{13}{*}{$5-\mathrm{HT}_{2 \mathrm{~A}}$} & & PDZ proteins* & $\begin{array}{l}\text { Targeting to dendrites, activation of } \\
\text { silent synapses in the spinal cord }\end{array}$ & $\begin{array}{l}\text { (Li et al., 1999; Xia et al., } \\
\text { 2003b) }\end{array}$ \\
\hline & & PSD-95 & Trafficking, signaling & (Xia et al., 2003a) \\
\hline & & MUPP1 & & (Becamel et al., 2001) \\
\hline & & SAP97 & & (Becamel et al., 2004) \\
\hline & & MAGI2 & & (Becamel et al., 2004) \\
\hline & & MPP3 & & (Becamel et al., 2004) \\
\hline & & CIPP & & (Becamel et al., 2004) \\
\hline & Caveolin & & Internalization, signaling & (Bhatnagar et al., 2004) \\
\hline & ARF1-6 & ARF1-6 & Signaling & (Robertson et al., 2003) \\
\hline & MAP1A & & Targeting & $\begin{array}{l}\text { (Cornea-Hebert et al., } \\
\text { 2002) }\end{array}$ \\
\hline & JAK2/STAT3 & & & $\begin{array}{l}\text { (Guillet-Deniau et al., } \\
\text { 1997) }\end{array}$ \\
\hline & $\begin{array}{l}\text { Ribosomal S6 } \\
\text { kinase }\end{array}$ & & Signaling & (Sheffler et al., 2006) \\
\hline & Calmodulin & Calmodulin & $\begin{array}{c}\text { Receptor phosphorylation / } \\
\text { desensitization }\end{array}$ & $\begin{array}{l}\text { (Turner and Raymond, } \\
\text { 2005) }\end{array}$ \\
\hline \multirow[t]{2}{*}{$5-\mathrm{HT}_{2 B}$} & & PDZ proteins* & NO signaling & (Manivet et al., 2000) \\
\hline & & MUPP1 & & (Becamel et al., 2001) \\
\hline \multirow[t]{12}{*}{$5-\mathrm{HT}_{2 \mathrm{C}}$} & & PDZ proteins ${ }^{*}$ & Desensitization/resensitization & (Backstrom et al., 2000) \\
\hline & & MUPP1 & $\begin{array}{l}\text { Receptor clustering, } \\
\text { phosphorylation? }\end{array}$ & $\begin{array}{l}\text { (Ullmer et al., 1998) } \\
\text { (Becamel et al., 2001) } \\
\text { (Parker et al., 2003) }\end{array}$ \\
\hline & & PSD-95 & & (Becamel et al., 2002) \\
\hline & & SAP97 & & (Becamel et al., 2004) \\
\hline & & SAP102 & & (Becamel et al., 2004) \\
\hline & & MAGI-2 & & (Becamel et al., 2004) \\
\hline & & MPP3 & & (Becamel et al., 2002) \\
\hline & & Veli3/CASK/Mint1 & & $\begin{array}{l}\text { (Becamel et al., 2002; } \\
\text { Becamel et al., 2004) }\end{array}$ \\
\hline & & Calmodulin & & (Becamel et al., 2002) \\
\hline & & PICOT & & (Becamel et al., 2002) \\
\hline & & PTD4 & & (Becamel et al., 2002) \\
\hline & PTEN & & $\begin{array}{l}\text { Receptor dephosphorylation, } \\
\text { behavioral responses to drugs }\end{array}$ & (Ji et al., 2006) \\
\hline \multirow[t]{6}{*}{$5-\mathrm{HT}_{4}(\mathrm{a})$} & & SNX27 & Targeting, trafficking & (Joubert et al., 2004) \\
\hline & & NHERF-1(EBP50) & Targeting & (Joubert et al., 2004) \\
\hline & & MAGI2 & & (Joubert et al., 2004) \\
\hline & & MPP3 & & (Joubert et al., 2004) \\
\hline & & Veli 1-3 & & (Joubert et al., 2004) \\
\hline & & CRMP2 & Regulation of axon growth? & (Joubert et al., 2004) \\
\hline \multirow[t]{3}{*}{$5-\mathrm{HT}_{4(\mathrm{e})}$} & & CIPP & & (Joubert et al., 2004) \\
\hline & & nNOS & & (Joubert et al., 2004) \\
\hline & & Sec23 & Trafficking to plasma membrane? & (Joubert et al., 2004) \\
\hline
\end{tabular}


Table 1: 5-HTR accessory proteins and their role in receptor functionality.

Only receptor subtypes for which interacting proteins have been unambiuously identified are mentioned. * Refers to experiments in which the receptor PDZ binding motif has been deleted. 


\section{Figure legends}

\section{Figure 1}

Human gene structures of metabotropic 5-HT receptor (HTR) coding sequences. This figure was generated by using released data from the human genome project available on the NCBI site via the map viewer interface: (http://www.ncbi.nlm. nih.gov/mapview/). Build 36 version 1 was used to localize the exons, except for 5-HT5BR; which was only annotated on build 35. Column 1 Gene names and cytogenetic localizations. Column 2 Representations of the exon composition of the coding sequences and the part of the receptor encoded by each exon (open boxes exons, bridges splicing events, black boxes transmembrane domains, curved lines loops or $\mathrm{N}$ - or C-terminal domains, colors alternative exons and the receptor part encoded in the splice variants). Column 3 Name and size of the gene products and splice variants (aa amino acids). Column 4 Size of the complete coding sequence on the human genome (b bases, kb kilo bases).

\section{Figure 2}

RNA editing of 5-HT2CR transcripts. a Position of the editing sites (A-E) within the human 5-HT2CR mRNA and the predicted amino acid sequences are shown for the non-edited INI isoform and for the fully edited VGV isoform. b Comparison of 5-HT2CR editing efficiency at each editing site for the human brain (dark blue bars) and rat brain (pale blue bars).

\section{Figure 3}

Examples of well-documented regional and cellular localizations (pink) of 5-HT1ARs, 5-HT1B:1DRs, 5-HT2ARs, and 5-HT2CRs. They can be localized on cell bodies (either on 5-HT neurons or other neurotransmitter-containing neurons) or on axon terminals (of 5-HT neurons or other neurotransmittercontaining neurons). 5-HT2CRs are also localized on the choroid plexus (POMC pro-opiomelanocortin, CART cocaine- and amphetamine-regulated transcript).

\section{Figure 4}

5-HTR signaling pathways and effectors (blue 5-HTR signal transduction in neurons, gray signaling linkages only in transfected cell lines, PL phospholipase, ERK extracellular signal-regulated kinase, PK protein kinase, IP3 inositol triphosphate, DAG diacylglycerol, MAPK mitogen-activated protein kinase, NOS nitric oxide synthase, AHP after-hyperpolarization, JAK Janus kinase, STAT transcription pathway, ih hyperpolarization-activated current, Epa activated exchange factor). 


\begin{tabular}{|c|c|c|c|}
\hline Gene & Gene structure & Gene products & Cds \\
\hline $\begin{array}{l}\text { HTR1A } \\
5 q 11.2-q 13\end{array}$ & $\square$ & $5-\mathrm{HT}_{1 \mathrm{~A}}: 422 \mathrm{aa}$ & $1269 b$ \\
\hline $\begin{array}{l}\text { HTR1B } \\
\text { 6q13 }\end{array}$ & 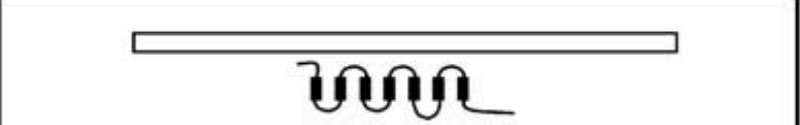 & $5-\mathrm{HT}_{1 \mathrm{~B}}: 390 \mathrm{aa}$ & $1173 b$ \\
\hline \begin{tabular}{|l|} 
HTR1D \\
1p36.3-p34.3
\end{tabular} & ช0 & $5-\mathrm{HT}_{1 \mathrm{D}}: 377 \mathrm{aa}$ & $1134 b$ \\
\hline $\begin{array}{l}\text { HTR1E } \\
\text { 6q14-q15 }\end{array}$ & 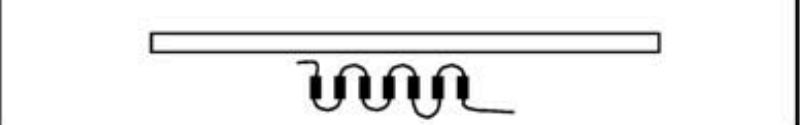 & $5-\mathrm{HT}_{1 \mathrm{E}}: 365 \mathrm{aa}$ & $1098 b$ \\
\hline $\begin{array}{l}\text { HTR1F } \\
\text { 3p12 }\end{array}$ & $\square$ & $5-\mathrm{HT}_{1 \mathrm{~F}}: 366 \mathrm{aa}$ & $1101 \mathrm{~b}$ \\
\hline $\begin{array}{l}\text { HTR2A } \\
5 q 14-q 21\end{array}$ & U & $5-\mathrm{HT}_{2 \mathrm{~A}}: 471 \mathrm{aa}$ & $>60 \mathrm{~kb}$ \\
\hline \begin{tabular}{|l|} 
HTR2B \\
2q36.3-q37.1
\end{tabular} & U & $5-\mathrm{HT}_{2 \mathrm{~B}}: 481 \mathrm{aa}$ & $>15 \mathrm{~kb}$ \\
\hline $\begin{array}{l}\text { HTR2C } \\
\text { Xq24 }\end{array}$ & U & $5-\mathrm{HT}_{2 \mathrm{C}}: 458 \mathrm{aa}$ & $>183 \mathrm{~kb}$ \\
\hline $\begin{array}{l}\text { HTR4 } \\
5 q 31-q 33\end{array}$ & in s & 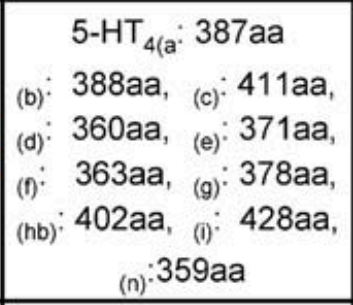 & $>185 \mathrm{~kb}$ \\
\hline $\begin{array}{l}\text { HTR5A } \\
7 \mathrm{q} 36.1\end{array}$ & पกि & $5-\mathrm{HT}_{5 \mathrm{~A}}: 357 \mathrm{aa}$ & $>14 \mathrm{~kb}$ \\
\hline $\begin{array}{l}\text { HTR5B } \\
2 q 14.1\end{array}$ & & Pseudogene & none \\
\hline $\begin{array}{l}\text { HTR6 } \\
\text { 1p36-p35 }\end{array}$ & गกी & $5-\mathrm{HT}_{6}: 440 \mathrm{aa}$ & $>15 \mathrm{~kb}$ \\
\hline $\begin{array}{l}\text { HTR7 } \\
\text { 10q21-q24 }\end{array}$ & $\Omega_{=} \theta_{d}$ & $\begin{array}{l}5-\mathrm{HT}_{7(\mathrm{a})}: 445 \mathrm{aa} \\
5-\mathrm{HT}_{7(\mathrm{~b})}: 432 \mathrm{aa} \\
5-\mathrm{HT}_{7(\mathrm{~d})}: 479 \mathrm{aa}\end{array}$ & $>116 \mathrm{~kb}$ \\
\hline
\end{tabular}

Figure 1 

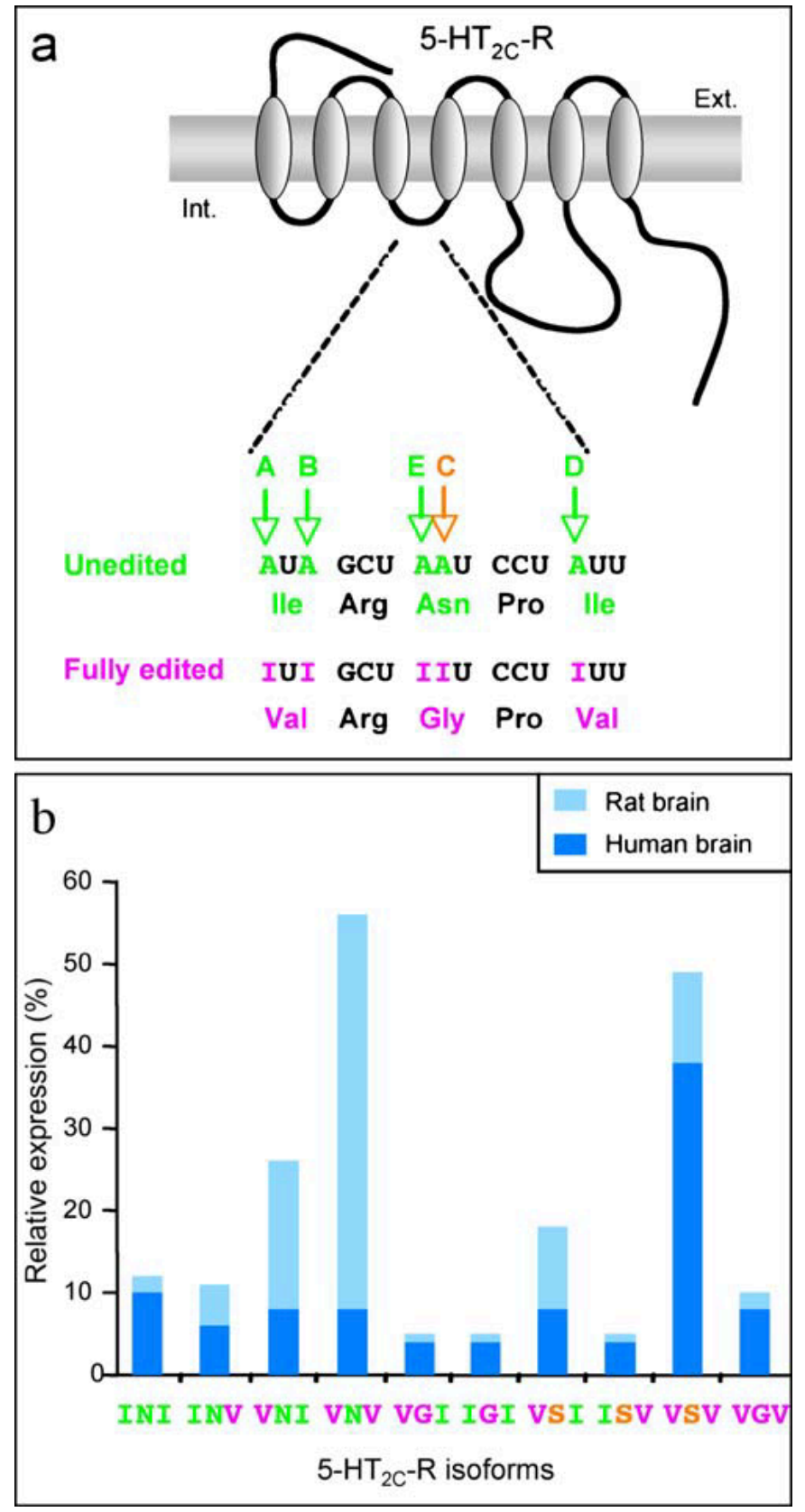

Figure 2 


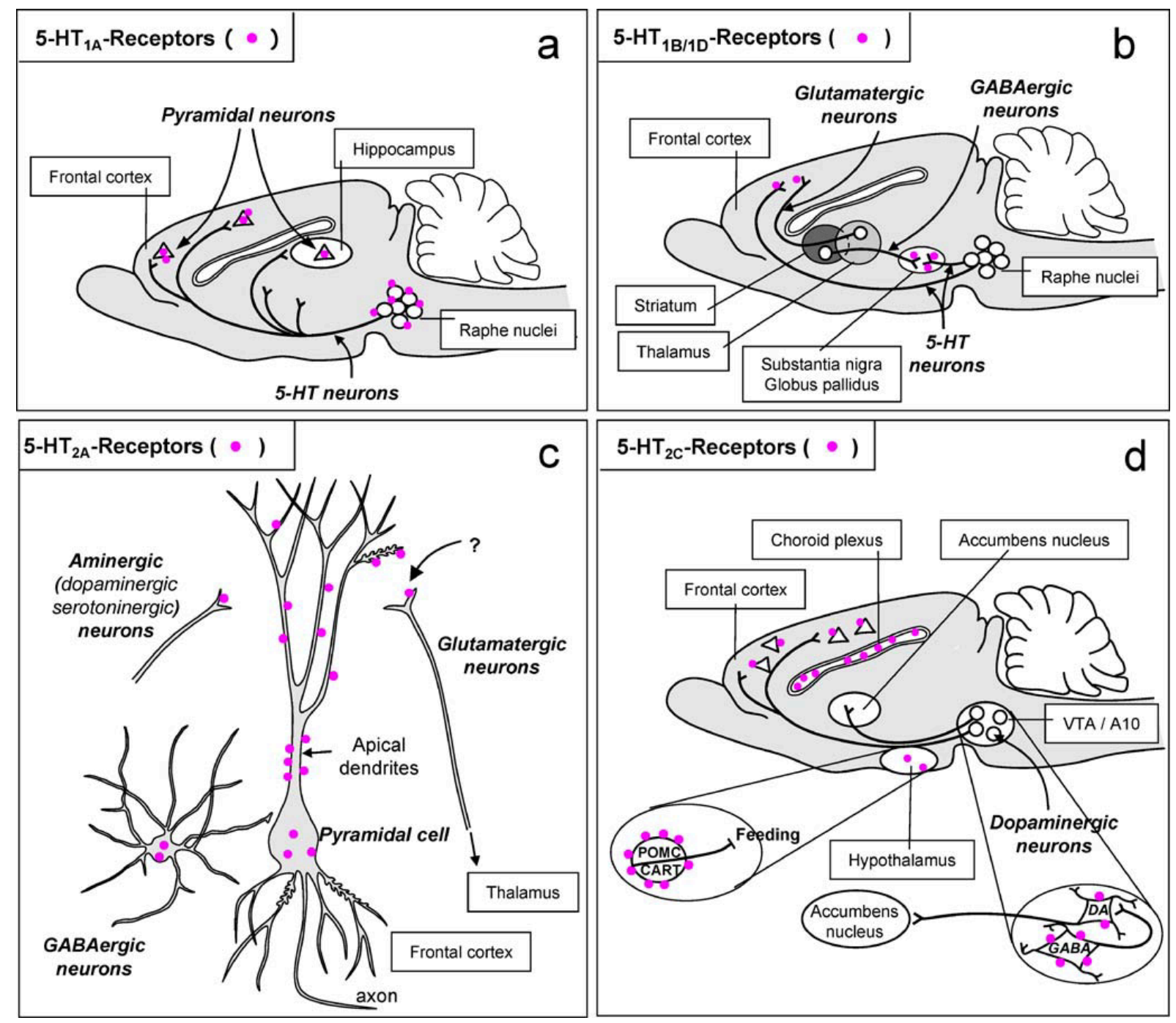

Figure 3 


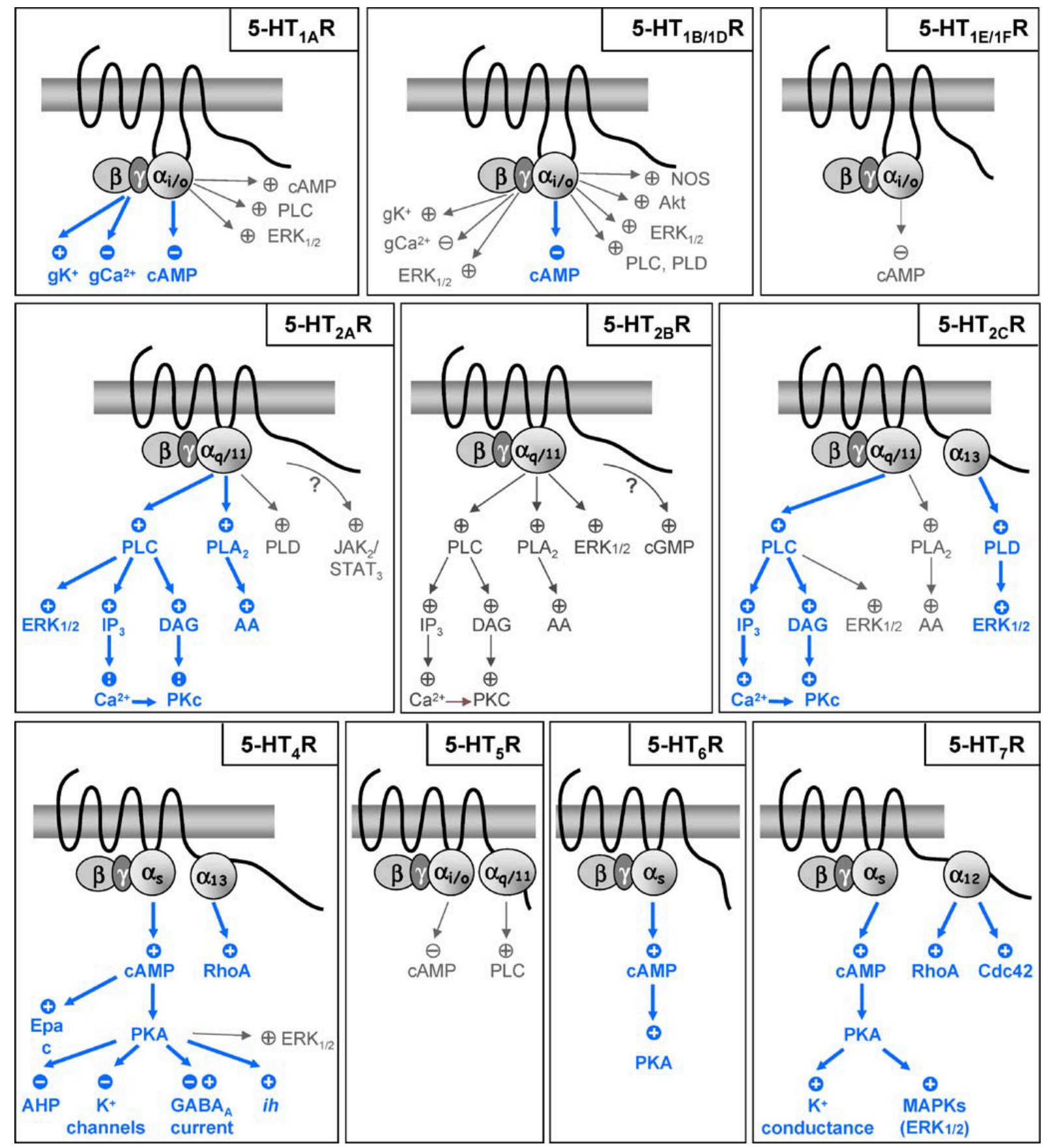

Figure 4 